\title{
Covid-19, Rural Poverty, and Women's Role in Decision-Making: Evidence from Khatlon Province in Tajikistan ${ }^{ \pm}$
}

\author{
Kamiljon Akramov, Lucia Carrillo, and Katrina Kosec
}

December 22, 2021

\begin{abstract}
The covid-19 pandemic has had devastating effects globally; it has caused health crises and economic recessions, leading unemployment to spike and disrupting food systems and supply chains. In the heavily remittance-dependent context of Tajikistan, however, migration has continued - and appears to have become increasingly dominated by men. In this context, what has happened to women's perceptions of economic prospects, as well as the well-being of their households? How has women's involvement in decision-making evolved? And to what extent do out-migration or in-migration of household members predict changes in women's decision-making power? We consider these questions using a September - October 2020 phone survey deployed in Khatlon province, Tajikistan that successfully tracked $87 \%$ of households that had been surveyed in person in 2018. We find that both genders have similar expectations for their agricultural production (harvests), but women are slightly more likely to identify concerns with rising prices and a lack of access to financial services. Overall, we find little in the way of evidence that women's involvement in intra-household decision-making declined as a result of the pandemicthough this is from a low base. However, we find that women are less likely than are men to report improvements in women's decision-making authority. Further, we find that out-migration of household members, which is dominated by men, is associated with improvements in women's decision-making power, particularly with respect to decisions about how to spend household income. Overall, our results point to the need for additional analyses of the gendered impacts of shocks on women in the Central Asia region.
\end{abstract}

Keywords: Poverty, covid-19, agriculture, migration, Tajikistan, gender

\footnotetext{
${ }^{ \pm}$This research was part funded by the CGIAR Research Program on Policies, Institutions, and Markets led by IFPRI, and the Ministry of Finance of the Russian Federation under IFPRI's Collaborative Research and Capacity Strengthening Program for Enhancing Agricultural Productivity and Food and Nutritional Security in Central Asia.
} 


\section{Introduction}

The covid-19 pandemic has had devastating effects globally; it has caused health crises and economic recessions, leading unemployment to spike and disrupting food systems and supply chains. The poor were especially negatively affected by lost or decreased incomes and remittances (Swinnen and McDermott, 2020). In Tajikistan, the pandemic slowed down the economy and created health, social, and economic pressures. Restrictions on population mobility and economic activity at home and abroad resulted in lower employment opportunities, reduced household income and migrant remittances, weaker consumer demand, and worsened food security (World Bank, 2020).

The world's poorest countries have been hardest hit on many levels. They have the least access to fiscal stimulus and other public investments, from healthcare to subsidies, to help households weather economic and health shocks. One of these countries is Tajikistan, where the government responded to the pandemic by deferring tax collections, boosting health and social spending, cutting interest rates, and asking banks to restructure loans and waive penalties (IFPRI, 2020; World Bank, 2020; and UNDP, 2020). While these measures helped ease the pandemic's negative impact on household welfare and livelihoods, food security deteriorated during the peak of the crisis, with rising shares reporting going hungry, reduced dietary diversity, and worries over obtaining enough food. Such households adopted coping mechanisms such as selling assets and reduced spending on food consumption and medical care (World Bank, 2020).

We had a unique opportunity to better understand how covid-19 has impacted rural livelihoods in Tajikistan via a phone survey carried out during September - October 2020 with a set of households surveyed during September 2018 in Khatlon province. Khatlon is Tajikistan's most populous and poorest province, selected as the zone of influence for USAID's Feed the Future program. According to the 2012 Tajikistan Demographic and Health Survey (DHS), over 63 percent of the population was in the lowest two quintiles of the national wealth index, which was the highest provincial average in the country. In 2014, extreme poverty in Khatlon was recorded at 21.6 percent, the highest province-level figure - compared with a national average of 16.8 percent (Statistical Agency under the President of the Republic of Tajikistan, Ministry of Health of Tajikistan, and ICF International, 2012; Statistical Agency under the President of the Republic of Tajikistan, 2015). Our 2020 follow-up survey had a very low attrition rate (approximately $12.8 \%)$.

We find that both genders have similar expectations for their agricultural production (harvests), but women are slightly more likely to identify concerns with rising prices and a lack of access to financial services. Out-migration appears to have become increasingly male-dominated during the pandemic but continues to be an important household livelihood strategy. Overall, we find little in the way of alarming evidence that women's involvement in intra-household decision-making declines as a result of the pandemic - though likely from a low base. However, we find that women are less likely to report improvements in their decision-making authority than are men. Further, we find that out-migration of household members, which is dominated by men, is associated with improvements in women's decision-making power, particularly with respect to decisions about how to spend household income. Overall, our results point to the need for additional analyses of the gendered impacts of shocks on women in the Central Asia region.

This paper is organized as follows. In Section 2, we provide background information on Tajikistan, and Khatlon province in particular. This describes the economic profile and poverty levels of the region, the importance of migration to the economy, the nature of women's empowerment and 
gender relations, and the qualitative impacts of covid-19 reported in existing literature. In Section 3, we describe in detail the 2018 and 2020 data collection efforts we undertook as well as our plan for the analysis - which includes a combination of descriptive statistics and regressions. In Section 4, we present our results. Finally, Section 5 concludes and provides lessons for future research.

\section{Background}

\subsection{Economic profile of Tajikistan}

Tajikistan is a predominantly rural country with 73 percent of its population living in rural areas. Its per capita gross national income using the Atlas method was estimated at US\$1060 in 2020 according to the World Bank (2021c). The country's economic base is dominated by its main export commodities (aluminum and cotton) and it is supplemented by remittances from Tajik nationals working abroad, the majority being men (IFAD, 2020).

Agriculture is one of the main economic sectors of the country's GDP and it plays a meaningful role in the livelihoods of its population. In 2020, agriculture contributed 23.8 percent of Tajikistan's GDP, and about 45 percent of employment was in agriculture (World Bank 2021c). Tajikistan is a predominantly mountainous country and only 5.3 percent of its total land can be used for crop farming (Akramov and Shreedhar, 2012). The country's agriculture sector includes two farming systems: upland areas dominated by wheat, potatoes, and horticulture along with rainfed pasturing, and lowland areas characterized by irrigated cotton in rotation with wheat. Moreover, there are three main groups of producers: those with small household plots (21 percent of arable land), dehkan (peasant) farmers (66 percent), and agricultural enterprises (13 percent) (IFAD, 2020; Tomas et al. 2021 (forthcoming)).

\subsection{Poverty}

Tajikistan has made great progress reducing its poverty rates during the last decade and its economy has been growing steadily at an average growth rate of 7 percent. However, job creation dynamics in the country have not been able to keep up with the fast-growing population. While the poverty rate decreased from 83 to 26.3 percent between 2000 and 2019, certain non-monetary poverty indicators remain high, particularly in rural areas where only 36 percent of the population has access to safe drinking water (World Bank, 2021b). The challenge remains to ensure the youth have productive job opportunities, including equitable opportunities for women in particular, who often confront harmful traditional gender norms that limit their opportunities for productive employment.

\subsection{Migration}

A lack of lucrative employment opportunities has served as a push-factor compelling many male Tajik individuals to migrate internationally, with the Russian Federation being one of the most important destinations. Currently, remittances account for approximately 30 percent of Tajikistan's GDP - among the highest shares in the world. Remittances are mainly used to cover food and other household expenditures, comprising up to 70 percent of household expenditures (World Bank, 2021d).

Additionally, given the large flows of (male-dominated) outmigration in the country, women often assumed increased responsibilities at home and, as a result, have become less likely to actively look for employment outside the household. Part of this is due to cultural norms facing women - especially mothers-which pressure them to continue to take on their normal domestic burdens in addition to many of those vacated 
by their migrant husbands. For example, they may need to manage household land plots and animals that had been previously tended by men. This reduces women's availability for income generating activities outside their household (World Bank, 2021a). It also has the potential to lead to time poverty, whereby women face increased working hours and less leisure time following male out-migration.

There is also some evidence to suggest lower school enrollment for children in households with migrant parents, although female-headed households are more likely to enroll children in school. Migration of household members lowers the probability of children's school enrolment by 10.3 percentage points, while the remittances, on average, offset the adverse effect of migration by up to 2.2 percentage points only. The negative impact of parental migration is also more significant than that of migration by other household members (Murakami, 2021).

\subsection{Women's empowerment and gender relations}

While the Government of Tajikistan has made great progress since 2010 towards greater gender equality, specifically in the areas of agriculture and education, there are other areas where large gender gaps remain (World Bank, 2021a). In Tajikistan, most households are headed by men. Only 23 percent of people live in households headed by women, and these are usually smaller, less-poor households compared to those headed by men (World Bank, 2021a).

Considering intra-household decision-making power, given the social norms and gender stereotypes that prevail in Tajikistan, and the erosion of communism that in some ways promoted gender equity, since 2012, women have become less engaged in decision-making. As most families in Tajikistan are marked by a patriarchal family structure, many newly married women are excluded from decision-making as decisions are often taken by one of the male members of their family (World Bank, 2021a).

During the last few years, Tajikistan has achieved gender parity in gross basic education (grades 1 to 9) enrollment. However, male enrollment exceeds female enrollment in preschool, secondary school, and tertiary education. Additionally, as women in secondary vocational schools almost exclusively study education, health care, or culture - traditionally low-paid sectors of the economy - they tend to earn lower wages than do men after leaving a vocational secondary school.

Moreover, labor force participation among women is significantly lower than that of men due to many factors. An important reason is the country's Labor Code (Article 216), which prohibits women's employment in underground jobs, difficult jobs, jobs in harmful conditions, or jobs linked to manual lifting and moving of heavy loads. This directly affects the opportunities women have to get high paying jobs given relatively higher wages paid for such jobs (World Bank, 2021a). Perhaps not surprisingly, in Tajikistan, the World Bank estimated that adult women's earned income is 4.5 times lower than that of men (World Bank, 2021a). Creating a favorable legal climate that supports women's access to decent jobs is thus a critical policy objective if Tajikistan is to promote gender equity in the labor market.

Currently, agriculture and education are the most gender-equal sectors of economic activity in Tajikistan, and women and men represent about 46 percent and 54 percent of the labor force in each sector, respectively. However, women working in agriculture often engage in seasonal work and report lacking formal contracts and receiving low pay (FAO, WFP, UNECE, UNICEF, WHO, and WMO, 2021). In sectors such as mining, energy and gas supply, transport, warehousing, and construction, gender disparities are stark. For example, in 2016, only 1 percent of all individuals employed in the construction sector and only about 3 percent of all employed in the transport sector were women. Health is the only sector with a large gender gap in favor of women, where 70 percent of all individuals employed are female. Women are certainly underrepresented in the sectors with better-paid jobs (World Bank, 2021a). 
The evidence also suggests that women in Tajikistan are more likely to be involved in agriculture and intrahousehold activities, such as cooking. This reflects traditional gender norms that proscribe men taking charge of many domestic responsibilities, thus contributing to greater time burdens for women. 


\section{Data and Empirical Strategy}

\subsection{Data}

\section{a. Description of the surveys used}

The data used in this study come from two household surveys conducted in September 2018 and during September-October 2020. The geographic areas covered by these surveys include 12 districts in southwest Tajikistan, which were beneficiaries of the USAID Feed the Future Tajikistan Agriculture and Water Activity (TAWA) (IFPRI/USAID, 2015; USAID, 2020). In total, the surveys covered 80 villages. ZAnalytics Group (also known as "Zerkalo"), a market and survey research firm based in Dushanbe, Tajikistan, executed the fieldwork with the guidance and help of IFPRI researchers.

The sample size for the 2018 survey was 1,200 households selected from local governments' household listings and the list of households who were beneficiaries of TAWA. The overall sampling rationale was to construct a sample by following a consistent protocol that employed random selection whenever possible. Within each district, we included all villages in our sampling frame. We then randomly selected several villages from each district proportional to the size of the population and agricultural (horticulture) production. We randomly sampled 15 households from each village, from among those engaged in horticulture production and sales.

The sample size for the 2020 survey was also 1,200 households, comprised of 1,047 households from the 2018 survey and 153 new households - reflecting attrition of only $12.8 \%$, which is quite low for a phone survey. It is these 1,047 households that comprise our main sample for analysis as they permit us to utilize 2018 data in several of our analyses. In a village where we could not reach a household from the 2018 sample (i.e., due to inability to reach the household or refusal), we randomly selected a replacement household from that same village using phone numbers provided in a recent survey our local partner conducted in the same village. Overall, the households in our sample had demographic and socio-economic characteristics similar to those of other rural households in the region (Takeshima et al., 2020).

Data were collected through face-to-face interviews in 2018 and by telephone in 2020. Phone numbers for each sample household were collected in the 2018 survey or other previous studies, and then utilized for follow-up in 2020. We believe that our data collected via phone calls are reliable for several reasons. First, since the respondents were from the 2018 survey sample, we had spoken with them previously, and their familiarity with our team helped build trust with our enumerators. Second, responding by phone also gave the interviewees the appearance of greater anonymity and may, therefore, hopefully, yield more reliable responses.

In 2018, the primary intended survey respondent was either the household head or the most informed household member. In addition, a module on time allocation was answered by each adult woman in the household. In 2020, the intended survey respondent was the primary respondent from the 2018 survey. However, while we collected information from 1,047 households that were surveyed in both 2018 and 2020, for only 930 of the households present in the 2020 dataset we were able to talk with the same main respondent surveyed in 2018. From these 930 households, we had 835 main respondents whose individual information was available in the 2018 survey. In this regard, our full sample comprises 1,047 households, but for some analyses that rely on individual characteristic, we use the reduced sample of 835 .

The survey instrument in 2018 contained multiple modules and collected information on household characteristics and assets, dwelling characteristics, women's empowerment in agriculture, women's nutrition and dietary diversity, households' participation in aid programs, migration and remittances, 
agricultural land ownership and land characteristics, agricultural assets, crop and livestock production, agricultural income, access to agricultural inputs and services, and participation in agricultural value chains. The women's empowerment in agriculture module collected information on women's time allocation, access to productive assets and credit, participation in household decision-making related to production and income, and group participation.

The number of modules in the 2020 survey instrument was reduced substantially from the 2018 instrument given the inherent challenges of overly long phone surveys and the known benefits for data quality of a shorter instrument (Ambler et al. 2021). This survey round collected information on household composition changes; the effects of pandemic control measures on household income and expenditures; migration and remittances; intrahousehold relationships and other social aspects; household dietary diversity and coping strategies; agricultural production; and access to inputs and services. We specify the exact wording of all variables used in our analyses in Appendix A.

\section{b. Respondents' characteristics}

Among those respondents for whom we have gender data (only for the 835 out of 1,047 total respondents that answered the survey in both of the two rounds in which their household took part), approximately 86 percent were women. Thus, we should interpret this paper as mostly providing information about women's perspectives. Of course, where an outcome relates to the household as a whole, her response should be considered to reflect that well - especially given that enumerators were asked to talk to the head or the most knowledgeable member (i.e., where women are not heads, they are at least perceived to be knowledgeable).

It is useful to understand how our respondents differ from other adult (age 18 or older) household members. For this comparison, we used information from the 2018 survey, given that the individual characteristics were only gathered by the survey that year. We performed a t-test to compare both groups. Table 1 shows results from two t-tests, one comparing adult female household members with female respondents, and the other comparing adult male household members with male respondents.

We notice that while female respondents and adult female members have significant differences in literacy, current school enrollment, Russian proficiency, and age, the significant differences for male respondents and members were age and literacy - though we acknowledge that statical power to detect differences is lower given the much lower sample of male respondents compared to female respondents. Overall, respondent women tend to be older, more literate, less likely to be still studying, and slightly more likely to speak Russian. This may reflect, for example, mothers-in-law being slightly more likely than daughtersin-law to be chosen (and agree) to be the respondent to the survey.

Table 1: Individual characteristics of respondents and family members.

\begin{tabular}{|c|c|c|c|c|c|c|}
\hline \multirow{3}{*}{ Variable } & (1) & (2) & (3) & (4) & $(5)$ & (6) \\
\hline & $\begin{array}{c}\text { Adult female } \\
\text { members }\end{array}$ & $\begin{array}{l}\text { Adult male } \\
\text { members }\end{array}$ & $\begin{array}{c}\text { Female } \\
\text { respondents }\end{array}$ & $\begin{array}{c}\text { Male } \\
\text { respondents }\end{array}$ & $\begin{array}{c}\text { T-test } \\
\text { Difference }\end{array}$ & $\begin{array}{c}\text { T-test } \\
\text { Difference }\end{array}$ \\
\hline & Mean/SE & Mean/SE & Mean/SE & Mean/SE & $(1)-(3)$ & $(2)-(4)$ \\
\hline \multirow{2}{*}{ Age } & 34.597 & 36.755 & 40.177 & 48.983 & \multirow{2}{*}{$-5.580 * * *$} & \multirow{2}{*}{$-12.228 * * *$} \\
\hline & {$[0.508]$} & {$[0.373]$} & {$[0.425]$} & [1.159] & & \\
\hline \multirow{2}{*}{ Can read and write } & 0.906 & 0.959 & 0.946 & 0.863 & \multirow{2}{*}{$-0.040 * * *$} & \multirow{2}{*}{$0.096^{* * *}$} \\
\hline & [0.009] & {$[0.005]$} & {$[0.008]$} & {$[0.032]$} & & \\
\hline
\end{tabular}




$\begin{array}{lcccccc}\text { Currently attending } & 0.089 & 0.095 & 0.026 & 0.060 & 0.062^{* * *} & 0.035 \\ \text { school } & {[0.009]} & {[0.007]} & {[0.006]} & {[0.022]} & & \\ \text { Highest education } & 0.193 & 0.059 & 0.205 & 0.034 & -0.012 & 0.025 \\ \text { level: Basic or less } & {[0.012]} & {[0.006]} & {[0.015]} & {[0.017]} & & \\ \text { Highest education } & 0.719 & 0.727 & 0.718 & 0.658 & 0.001 & 0.069 \\ \text { level: Secondary } & {[0.014]} & {[0.011]} & {[0.017]} & {[0.044]} & & \\ \text { Highest education } & 0.084 & 0.214 & 0.074 & 0.299 & 0.010 & -0.085^{* *} \\ \text { level: Tertiary or } & {[0.009]} & {[0.010]} & {[0.010]} & {[0.043]} & & \\ \text { higher } & 0.412 & 0.840 & 0.460 & 0.846 & -0.048^{* *} & -0.006 \\ \text { Russian proficient } & {[0.015]} & {[0.009]} & {[0.019]} & {[0.033]} & & \\ (>=\text { satisfactory) } & & \end{array}$

The value displayed for $\mathrm{t}$-tests are the differences in the means across the groups.

$* * *, * *$, and $*$ indicate significance at the 1,5 , and 10 percent critical level.

In terms of occupation, overall, as we can see from Figure 1 that most of the respondents $(37 \%)$ were not currently working during September - October 2020. A full 35\% were working in the agriculture sectorspread across those working on their own dehkan farm (4\%), working as a member of a dehkan farm (13\%), or working as an agricultural wage-earner (18\%). Only 10 percent of respondents were retired and thus no longer economically active. Employment in the non-agricultural sector was only slightly lower than employment in agricultural wage labor (17\% of respondents).

Figure 1: Occupation of respondents

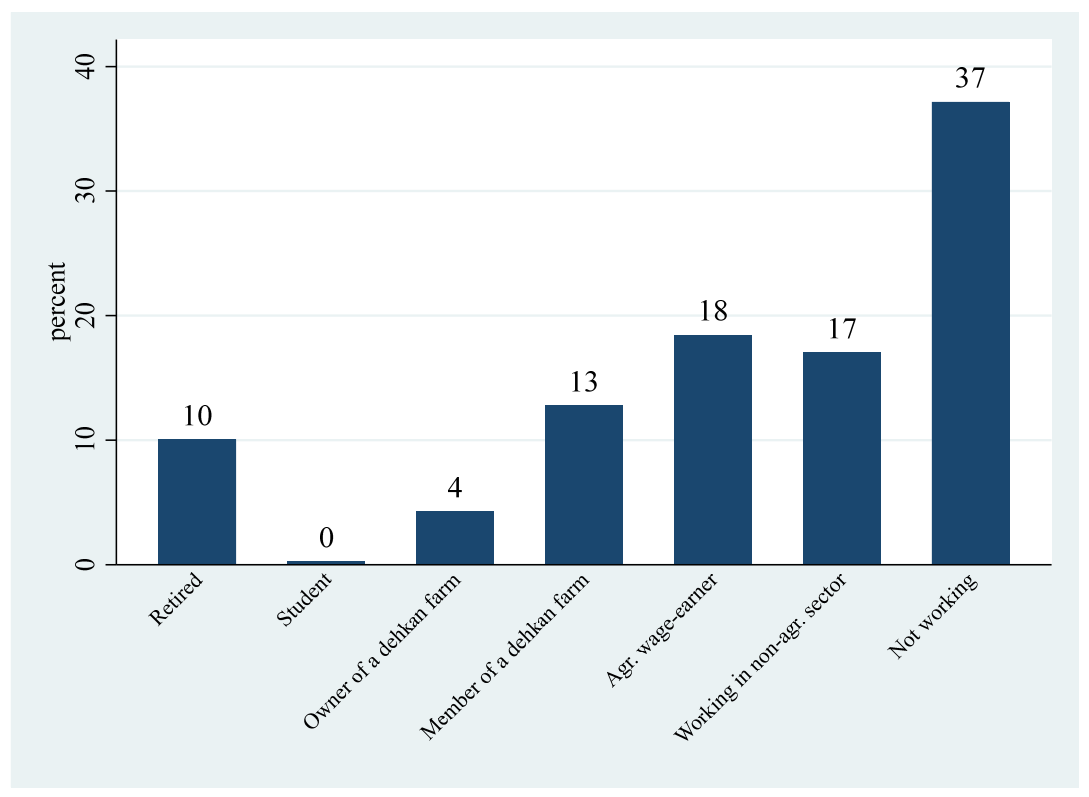

As noted at the outset, we have substantially more women respondents (86\%) than men (14\%), and as such, we have small sample and statistical power concerns when trying to compare across genders. However, we find it nonetheless instructive to consider how the 719 female respondents compare with the 116 male respondents. 
When we look closely to occupation statistics disaggregated by gender (Figure 2), our first striking finding is that the share of women that is not working is approximately 2 times greater than it is for men. This aligns with Tajikistan's context of women's low labor force participation.

Figure 2: Occupation of respondents by sex

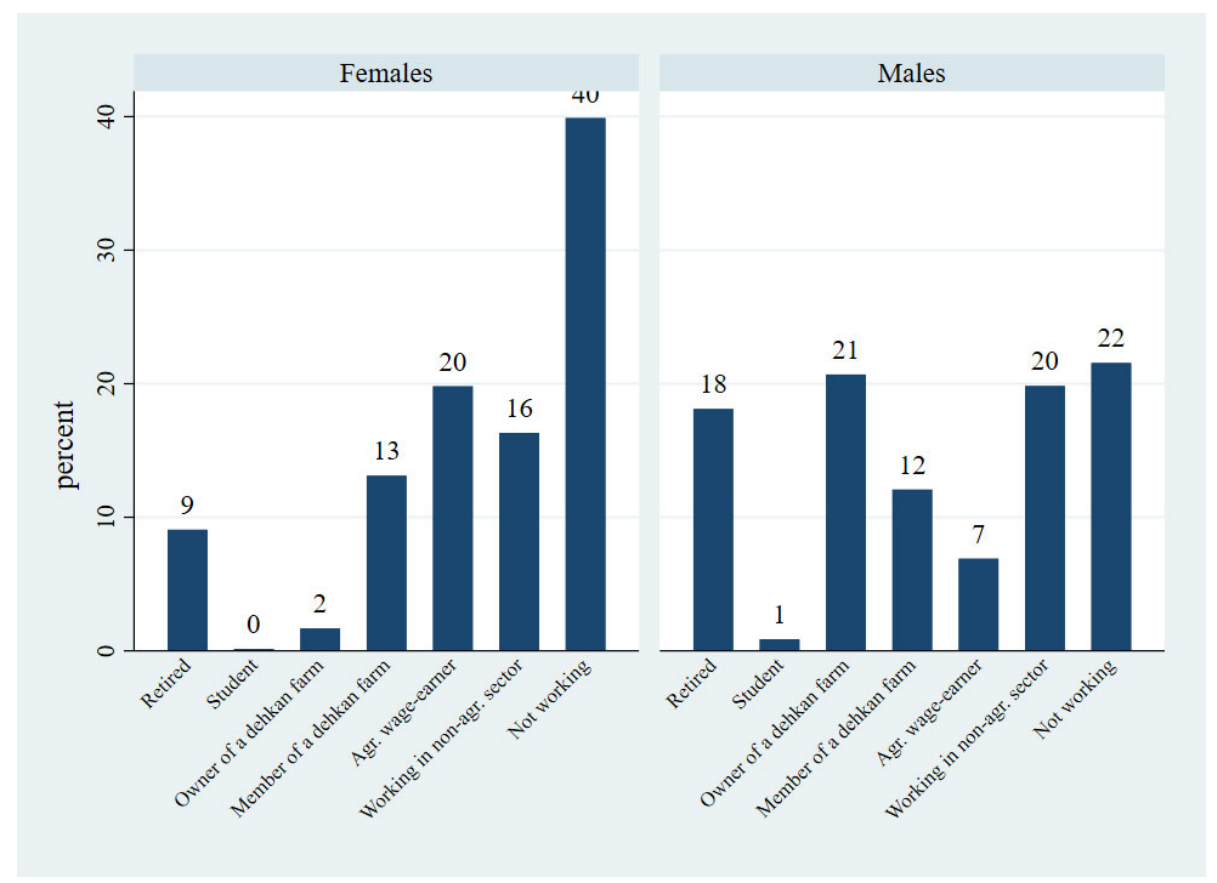

Finally, we provide evidence on features of respondents' households. Table 2 summarizes variables at the household level using variables collected in the 2018 survey. Considering ethnicity, we found that the vast majority of respondents identified as being either Tajik (57\%) or Uzbek (28\%). The average number of rooms in the households was 4.2. Turning to housing conditions, we found that 75 percent of households had floors in good conditions (painted woods floors, linoleum, or concrete); 99 percent has access to electricity; 64 percent used piped gas or electricity for cooking; and 27 percent had piped water (coming into the dwelling or yard) as their main source of drinking water.

Table 2: Household characteristics (2018)

\begin{tabular}{lc}
\hline Variables & Mean $/ \boldsymbol{S D}$ \\
\hline \hline \multirow{2}{*}{ HH Ethnicity: Tajik } & 0.572 \\
& {$[0.495]$} \\
HH Ethnicity: Uzbek & 0.282 \\
& {$[0.450]$} \\
HH Ethnicity: Turkmen & 0.018 \\
& {$[0.131]$} \\
HH Ethnicity: Other & 0.001 \\
& {$[0.029]$}
\end{tabular}




\begin{tabular}{lc} 
Number of rooms in the house & 4.213 \\
& {$[1.890]$} \\
Floors: 1=Painted wood- linoleum- concrete & 0.757 \\
Main source of drinking water: 1= piped & {$[0.429]$} \\
into dwelling/yard or tap & 0.274 \\
Has electricity & {$[0.446]$} \\
Main fuel for cooking: 1= Electricity or & 0.998 \\
piped gas & {$[0.041]$} \\
\hline
\end{tabular}

Table 3 summarizes a few other household characteristics using information collected in 2020 . We found that only 27 percent of the respondents were household heads. Also, we found that almost half (48\%) of respondents were currently working, and that the average number of household members with an active job was 2.6.

Table 3: Household characteristics (2020)

\begin{tabular}{lc}
\hline Variables & Mean/SD \\
\hline \hline \multirow{2}{*}{ Head of household } & 0.268 \\
& {$[0.443]$} \\
Respondent is currently working & 0.482 \\
& {$[0.500]$} \\
Number of household members with a job & 2.645 \\
& {$[1.848]$} \\
\hline
\end{tabular}

\section{Results}

Our results proceed in several parts. First, we characterize respondents' perceptions of how they anticipated covid-19 would affect them. We consider their harvest, prices, and access to financial services. We show results overall as well as by gender - where the caveats stated above about our sample being mostly women again apply to interpretation of our gender-disaggregated estimates. Second,

\subsection{Perceptions of the economy}

In Figure 3, we analyze harvest expectations for all respondents. What is first clear is that in general, respondents are optimistic; only 31 percent of respondents manifested low expectations for the harvest this year compared to other years. The modal response (39\% of respondents) was that they expected their harvest to be slightly higher. Despite market disruptions present at the time of our survey, this suggests that favorable growing conditions, limited disruptions in access to agricultural inputs, government-provided support, or other factors helped in some ways to support agriculture-dependent households during the covid19 pandemic. Moreover, comparing male and female respondents suggests that there are not considerable differences in their harvest expectations. 
Figure 3: Harvest expectations- What is your expectation about overall harvest this year?

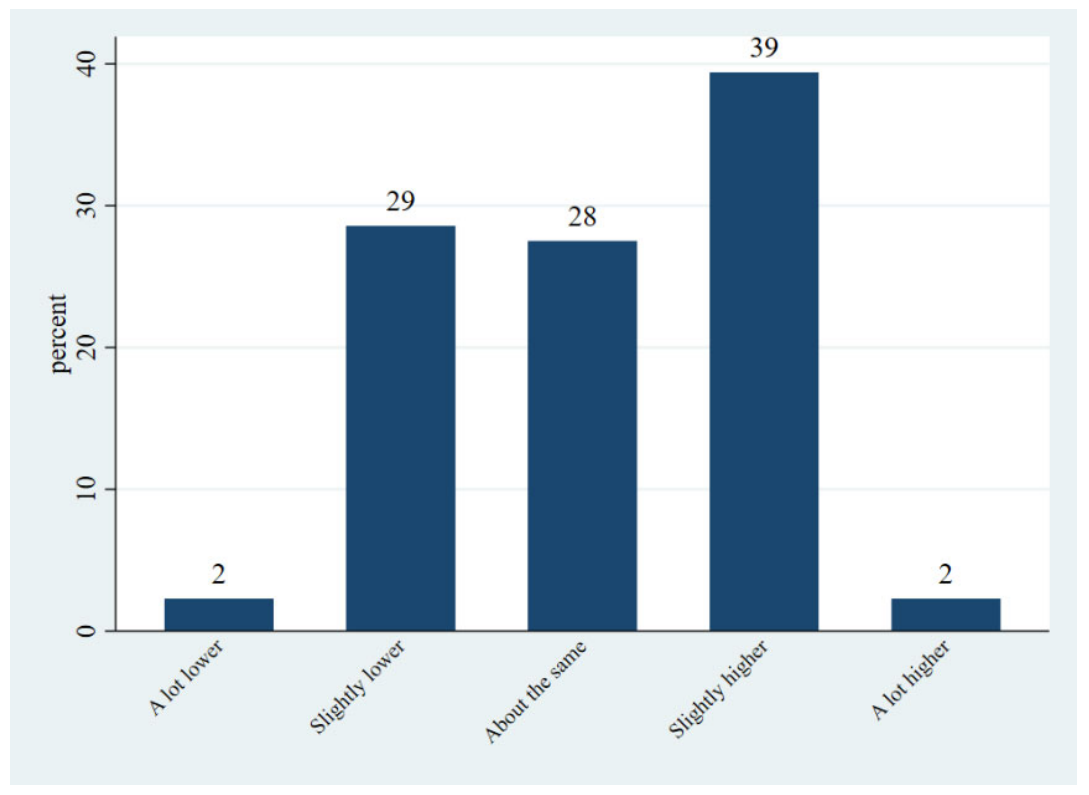

Figure 4: Harvest expectations by sex

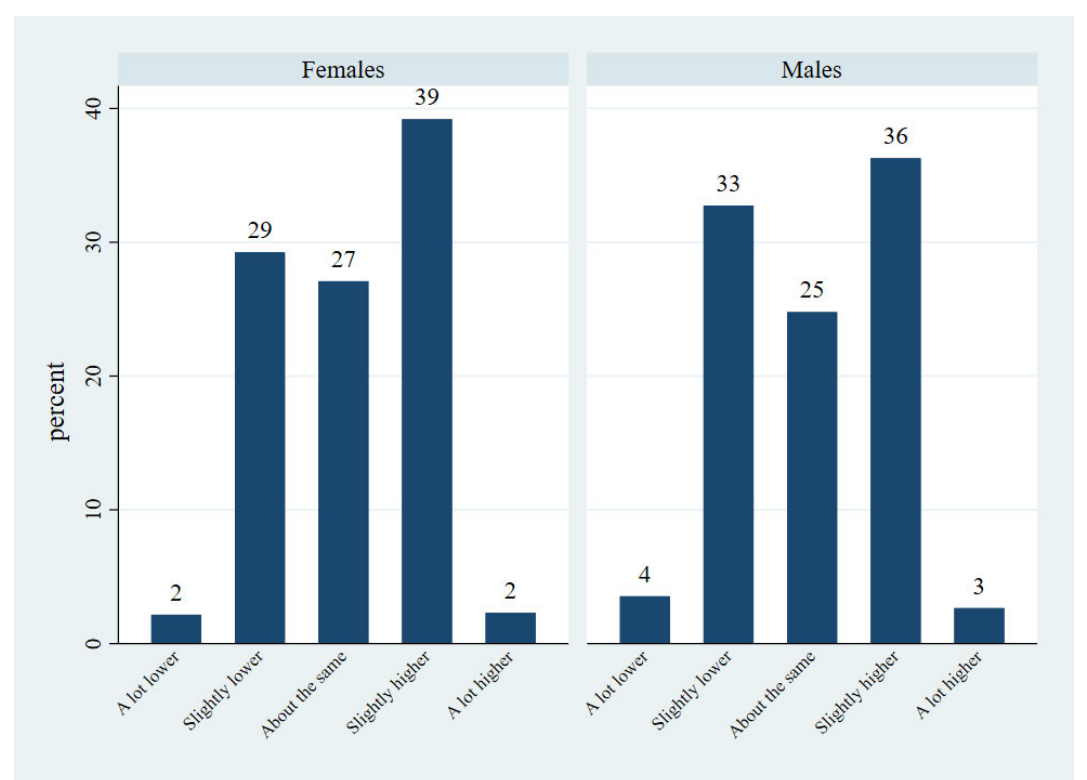

We next explored the price expectations respondents had during 2020, which were likely to be substantially impacted by the Covid-19 pandemic. In Figure 5, we noticed that generally, most of respondents - a full 58 percent - expected higher prices. However, when we analyze responses by gender (Figure 6), we saw that women have higher price expectations than men: while 59 percent of female respondents expected higher prices, only 43 percent of male respondents expected higher prices for the next season. This may reflect different information sets possessed by each gender - though we cannot say which one is more accurate than the other. 
Figure 5: Price expectations - Relative to the last year, do you anticipate you will receive higher or lower prices for your products?

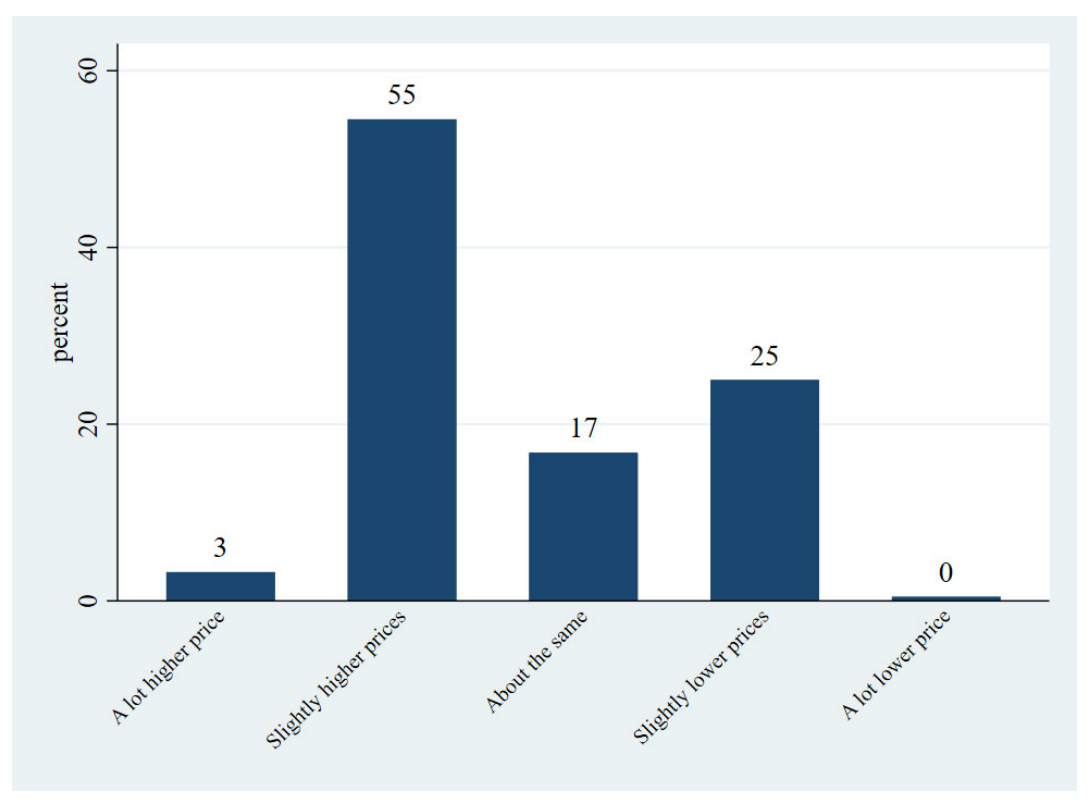

We also explored the general perception of the availability of financial support that individuals had been able to access during 2020 (Figure 7). Overall, most respondents (36\%) mentioned that financial support was more accessible in 2020 than in 2019, while a slightly smaller group (34\%) manifested the opposite. Conversely, when we see the results by sex, we noticed that a large share of men (42\%) reported that financial services were easier to access than in the past, while only 35 percent of women reported the same (Figure 8). This may reflect gender differences in the degree of financial inclusion that were accentuated by various disruptions brought about by covid-19.

Figure 6: Price expectations by sex

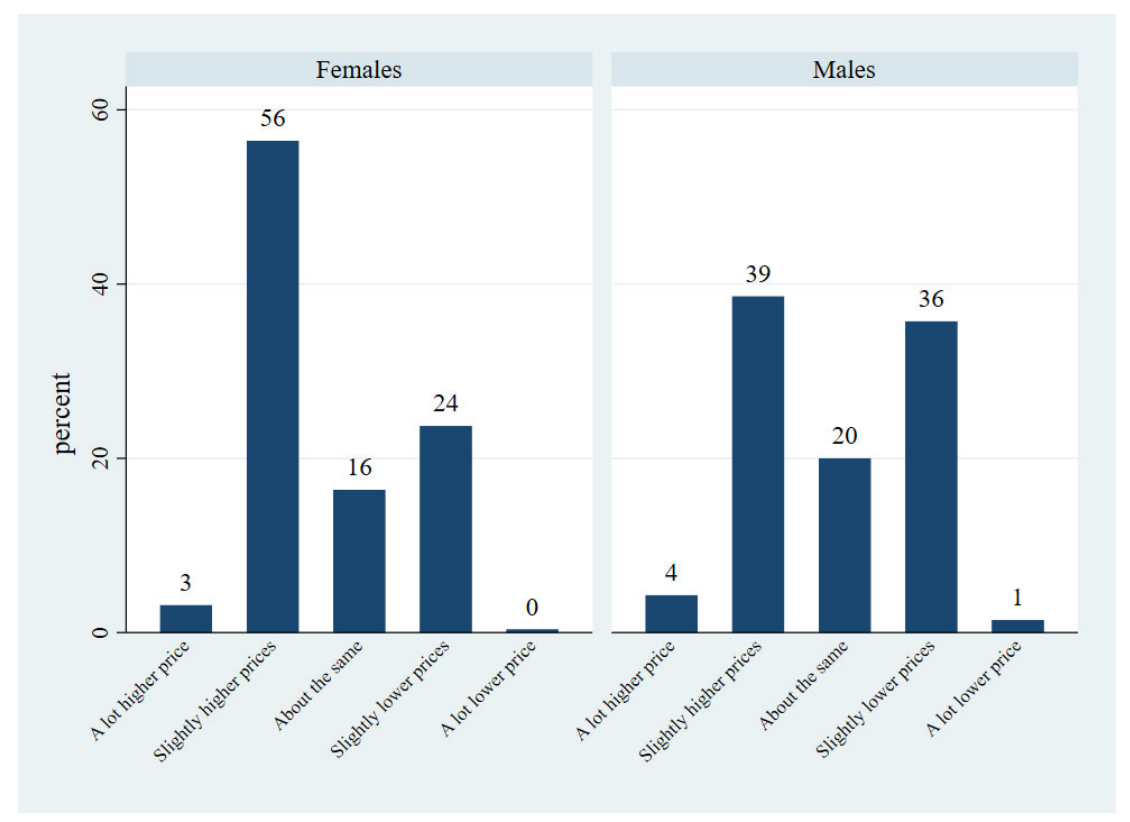


Figure 7: Perceptions of financial support availability - Relative to last year or a normal year, how difficult is it to get FINANCIAL support/credit this year?

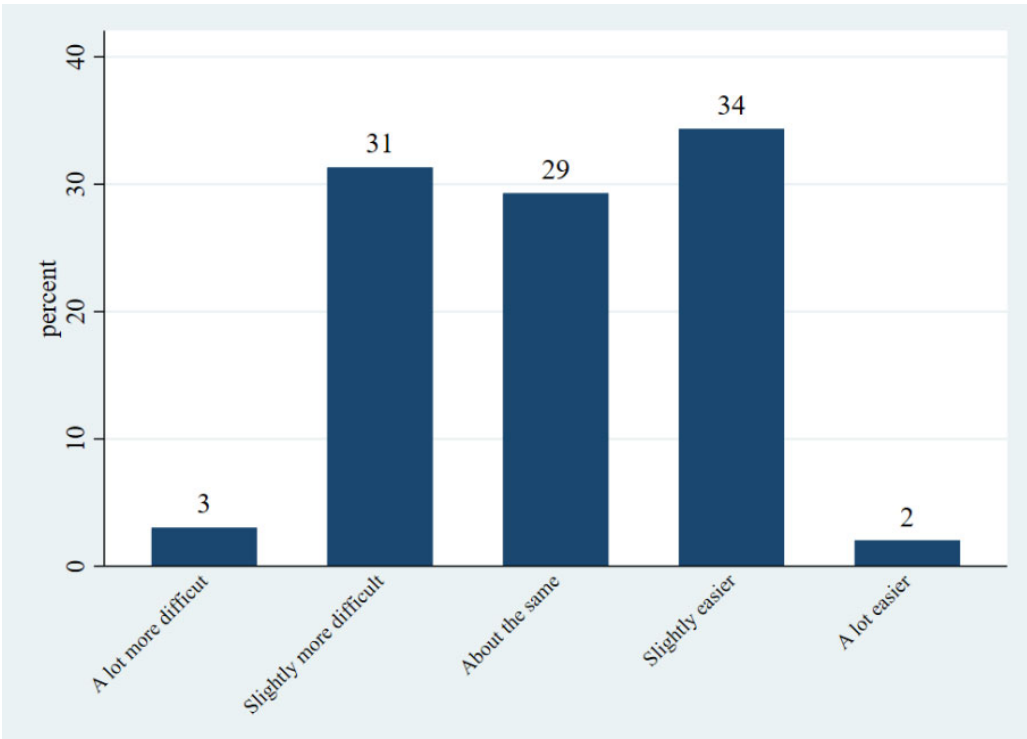

Figure 8: Perception of financial services availability by sex

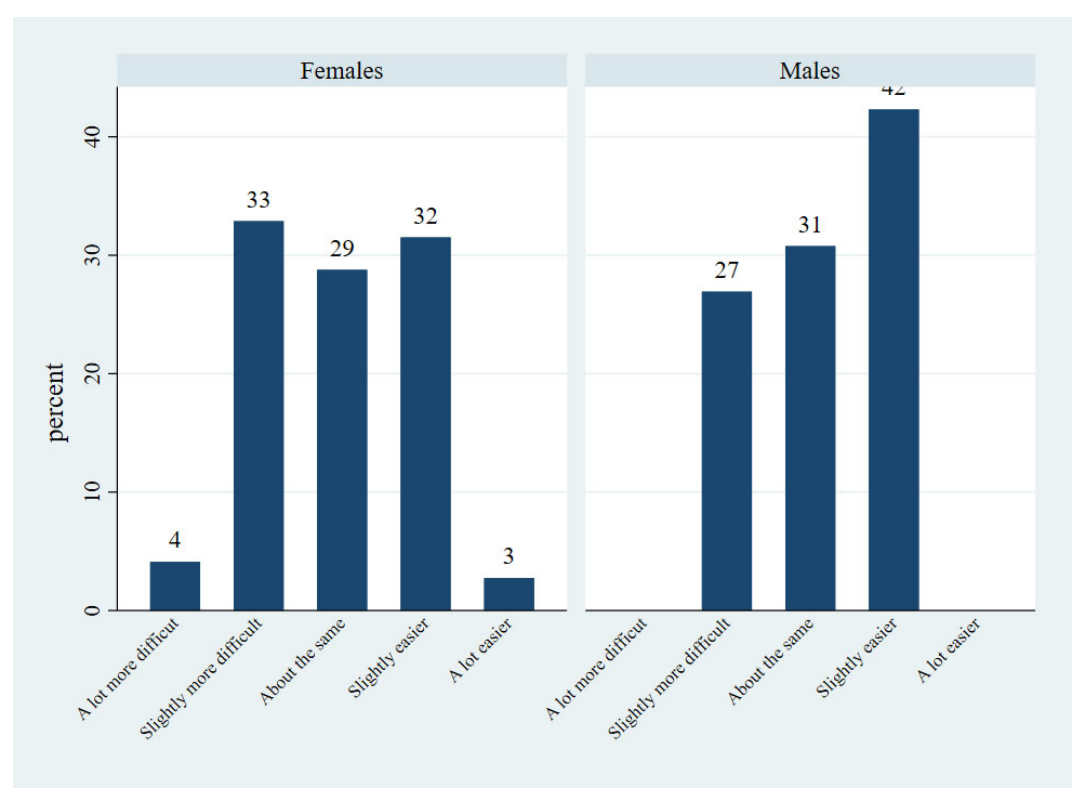




\subsection{Migration}

We next analyzed the migration patterns of Tajik individuals in 2 ways: (1) migration that occurred during the period between 2018 and 2020; and (2) migration dynamics that occurred during 2020 and which could be attributed to the covid-19 pandemic. For (2), we approximated the number of migrants that left the households due to the pandemic by asking the main respondent in 2020 if there was any member who, at the time of the survey, was away. While this might not accurately report the number of out-migrants due to the pandemic, we are confident that this number might be a very similar one.

We found that 28 percent of households reported having a migrant (either an in-migrant or an out-migrant) that migrated during the period between 2018 and 2020. Additionally, for the migration occurred during 2020, we found that the share of households reporting a migrant was even higher: 47 percent of households reported having at least one type of migrant for that period.

Figures 9 (displaying raw numbers of migrants by gender) and 10 (displaying shares of migration by gender) reveal that between 2018 - 2020, of the total number of in-migrants, adult women represented 99 percent of that group, meaning that during that period, men were unlikely to return to their origin households following a migration episode, or otherwise migrate in to one of our sample households (e.g., from another household elsewhere in Khatlon). This reflects cultural traditions in Tajikistan whereby women, upon marriage, move into their husband's household rather than the reverse. While we lack data on migration motives during 2018 - 2020, marriage is a known, common motive for women's migration in patrilineal social systems.

Moreover, reviewing out-migration flows during 2018 - 2020, we noticed that from the total number of out-migrants, women and men represented similar shares. While the high rates of female migration might seem surprising, it is known that when men migrate permanently, their wives often accompany them (Kosec et al., forthcoming). Further, heavy flooding and landslides occurred in several districts in Khatlon during this time - possibly leading larger numbers of women and men to relocated together (Migrants and Refugees, 2020).

Conversely, when we analyze the migration flows more clearly due to the pandemic (i.e. during the course of 2020), we found a reversal of the pattern of in-migration observed during 2018 - 2020. Specifically, instead of being nearly entirely driven by women migrating in, it becomes nearly entirely driven by men migrating in during 2020. This is consistent with reverse migration by men in response to border restrictions, lock-downs, and plummeting work opportunities abroad. It is also consistent with families holding off on marriages, or on brides relocating to a husband's home, amid a time of financial downturn and lockdowns (leaving less ability to make marital payments and making it harder to finance or hold a wedding).

During the pandemic, we also find that out-migration is male-dominated. It is interesting that migration does still occur at a high rate (reflecting the remittance dependence of the context), but unlike during 2018 -2020 , men are generally migrating alone These findings support the general dynamics for Tajik migrations where men dominate migration given social norms prevailing in the country. 
Figure 9: Migration dynamics (\# of migrants)
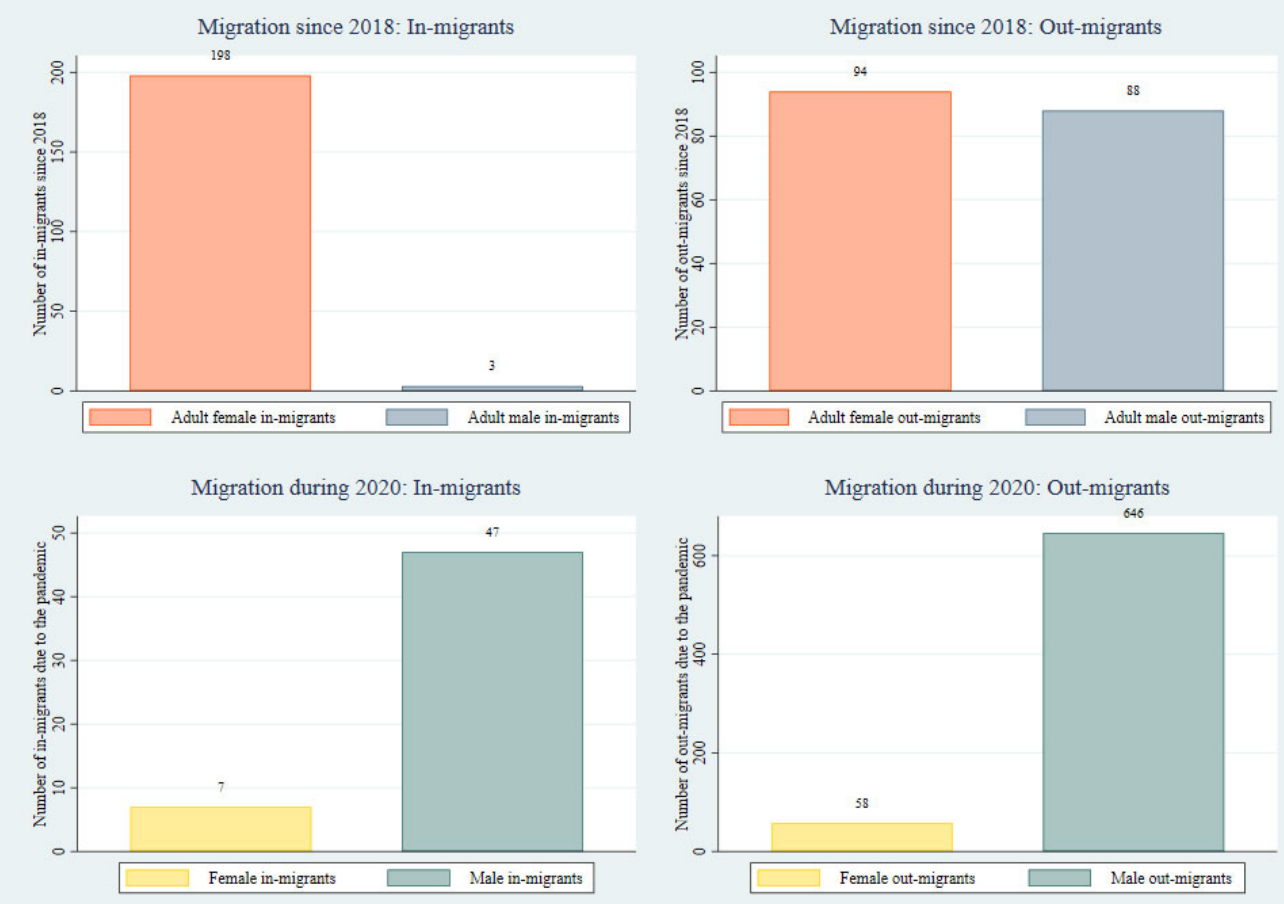

Figure 10: Migration dynamics (\%)

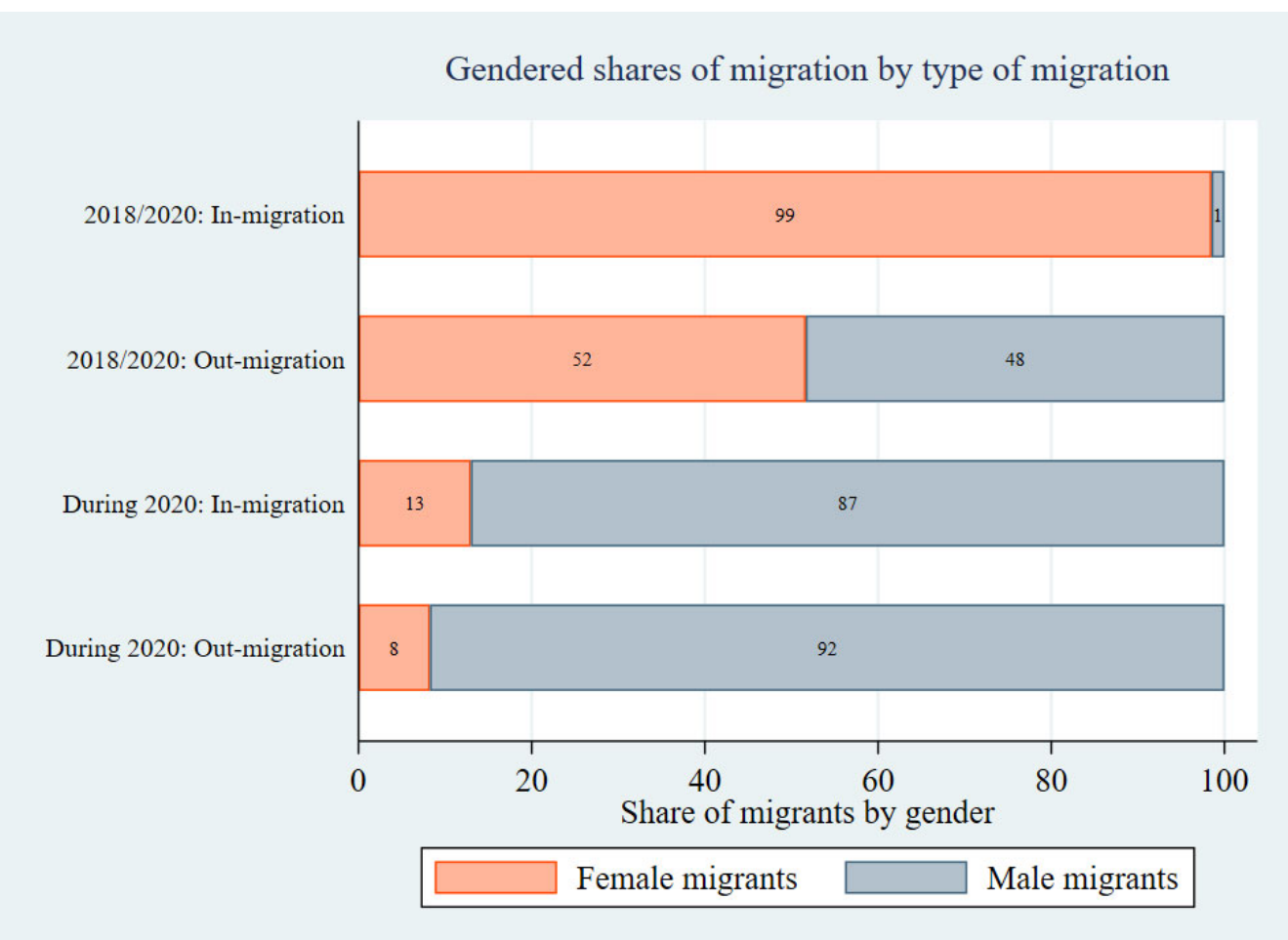




\subsection{Intra-household decision-making}

We used our full sample to analyze perceptions about how women's involvement in decision-making about spending household income changed as a result of the covid-19 pandemic. In particular, we consider three decisions: spending household income, managing household assets, and making decision's about a woman's own children (e.g., education, healthcare, work, etc). We analyze each in turn.

\subsubsection{Income}

We first consider who makes decisions about spending a household's income. We noticed that the general perception among our respondents was that it did not change, or if it did, that women had a higher degree of involvement in income spending decisions during the pandemic compared to a year prior (i.e., during September - October 2019). Only 22 percent of respondents manifested that their perception was that women had a lower involvement in income spending decisions. This is interesting in light of our sample being comprised of mostly women respondents - who may have greater incentives than their male counterparts to convey a sense of lost power, and who might be expected to exhibit less social desirability bias (i.e., to show that they are an egalitarian spouse in front of enumerators they do not know).

\section{Figure 11: Perceptions about how women's involvement in decision-making about spending household income changed due to the pandemic}

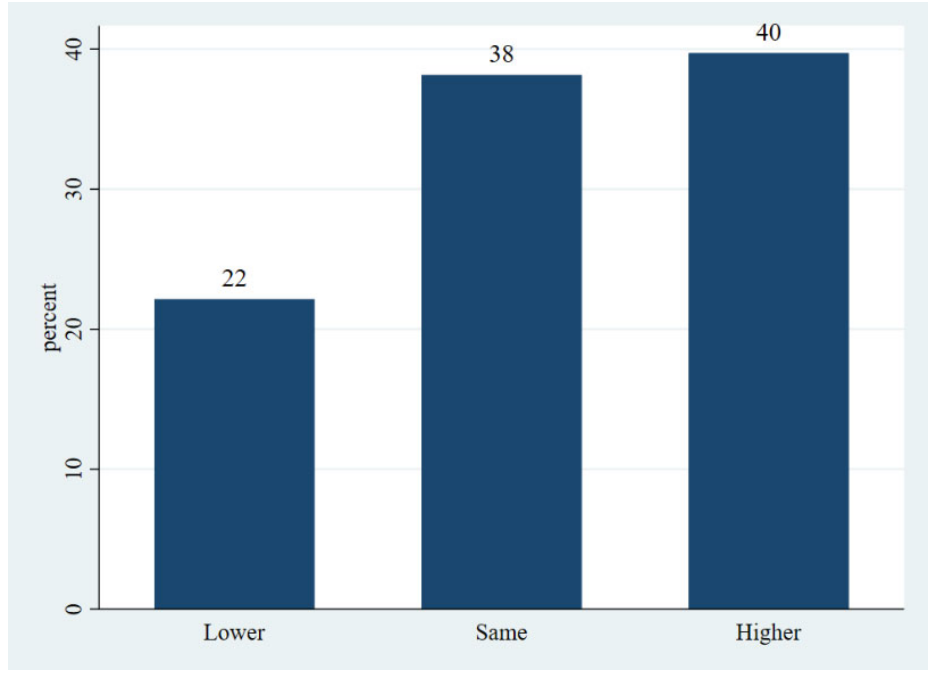

However, when using the reduced sample and disaggregating by sex, views seem slightly different between women and men. While 50 percent of male respondents think that women hold a higher involvement about income spending, only 39 percent of female respondents agreed. Additionally, 39 percent, mentioned that they did not think their involvement changed. 


\section{Figure 12: Perceptions about how women's involvement in decision-making about spending household income changed due to the pandemic by sex}

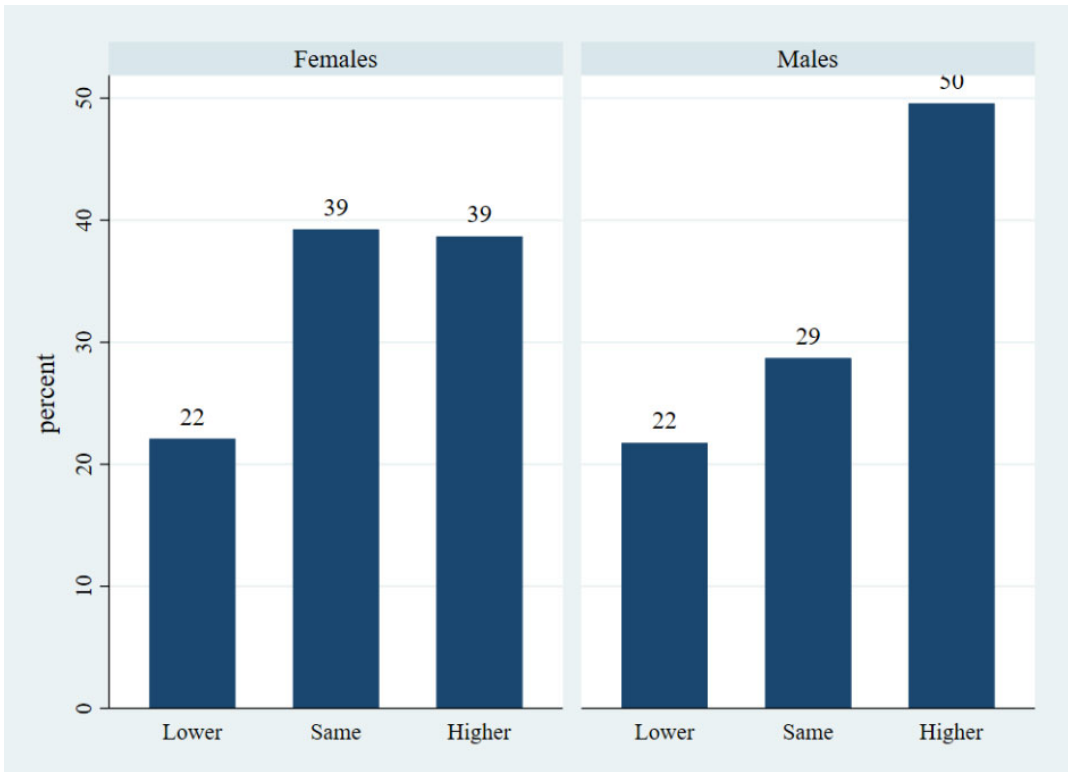

\subsubsection{Managing household assets}

Similarly, we assessed perceptions on women's involvement in assets management decisions within households and the results were not much different from perceptions over income-spending. While most of our full sample of respondents perceived that women's decision-making about asset management did not change (38\%) or was positively affected $(44 \%)$, when we analyzed the reduced sample, disaggregating the results by respondent sex, we found that as in the previous case, women and men have different perceptions: while 53 percent of male respondents perceived women as having a more important involvement with asset management decisions, only 43 percent of female respondents said the same. Both genders had similar shares of respondents saying that they thought women's decision-making agency in this domain had declined (18 percent of women and 19 percent of men). Thus, gendered differences appear to be mostly on the side of whether or not women had benefited from the pandemic in terms of decision-making over household assets. 
Figure 13: Perceptions about how women's involvement in decision-making about managing household assets changed due to the pandemic

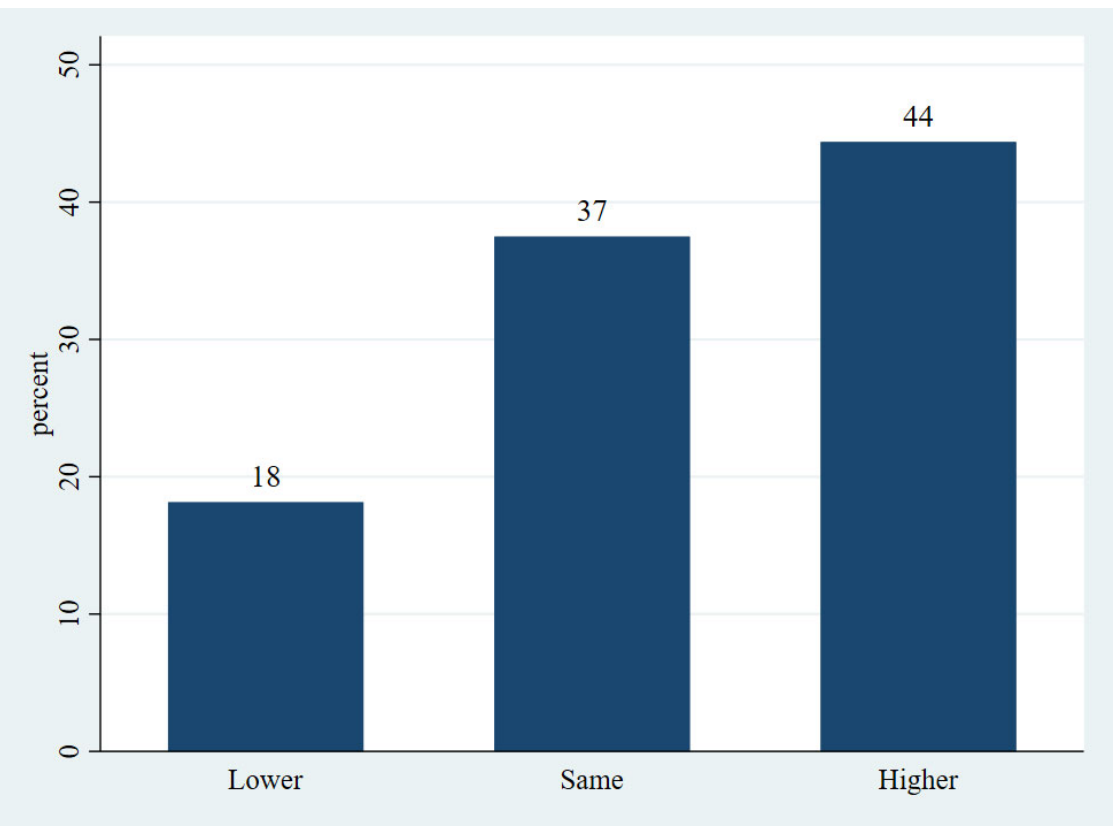

Figure 14: Perceptions about how women's involvement in decision-making about managing household assets changed due to the pandemic by sex

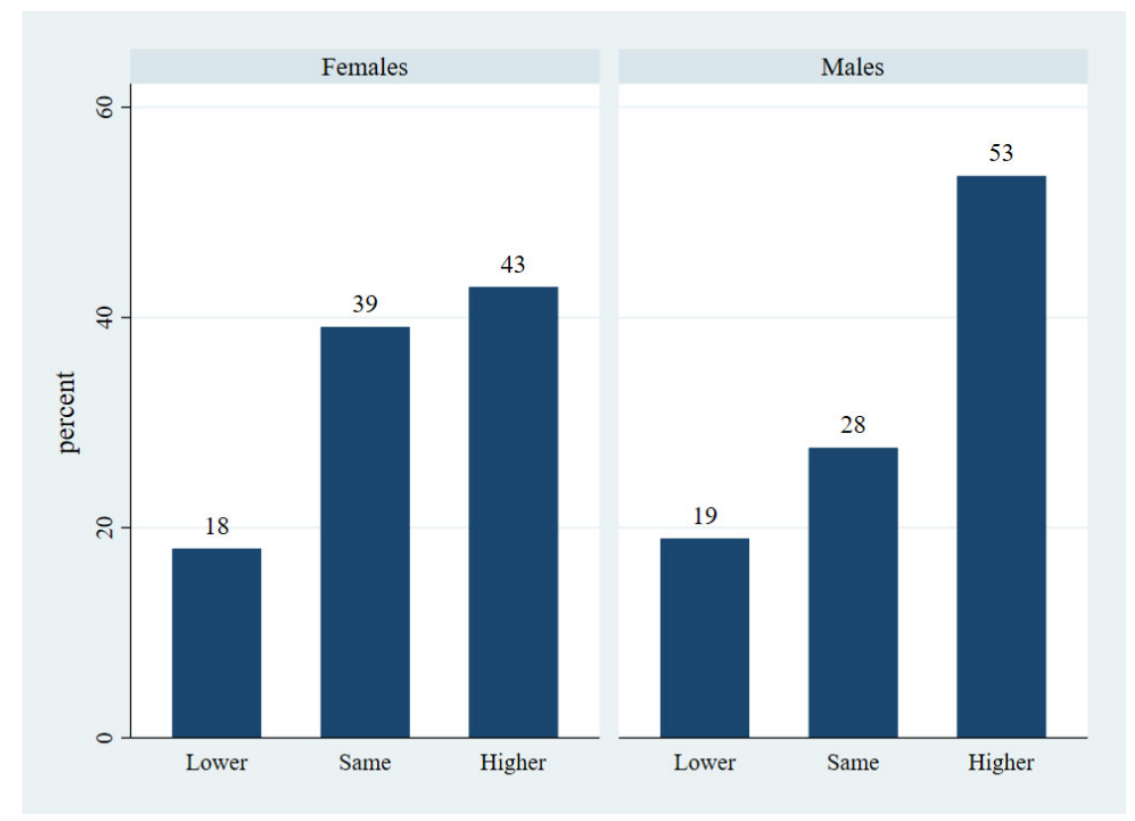




\subsubsection{Decisions about a woman's own children}

When considering perceptions about changes in women's involvement in decision-making about their own children, our findings are again similar to those for decision-making in other domains. In general, most of respondents in our full sample mentioned that women increased their degree of involvement in decision-making about children. Moreover, when we analyzed responses by gender, we noticed that perceptions by gender were very similar. While 72 percent of female respondents perceived a higher degree of involvement in decision making about children, similarly a 78 percent of male respondents agree on that.

It is interesting that the pandemic, which resulted in school closures as part of lockdowns, was actually seen by respondents (the majority of them women themselves) as increasing women's decision-making authority over issues related to children. The proximity to children that the pandemic offered could be one possible reason.

Figure 15: Perceptions about how women's involvement in decision-making about their own children changed due to the pandemic

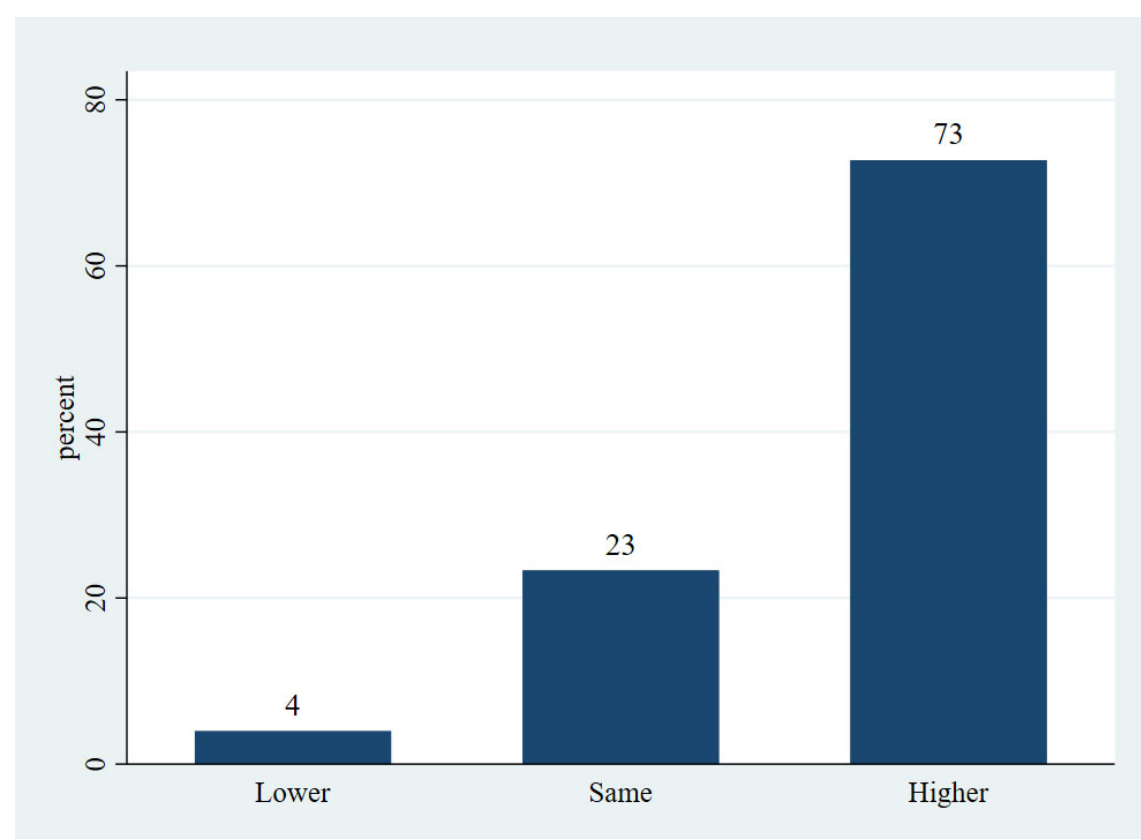


Figure 16: Perceptions about how women's involvement in decision-making about their own children changed due to the pandemic by sex

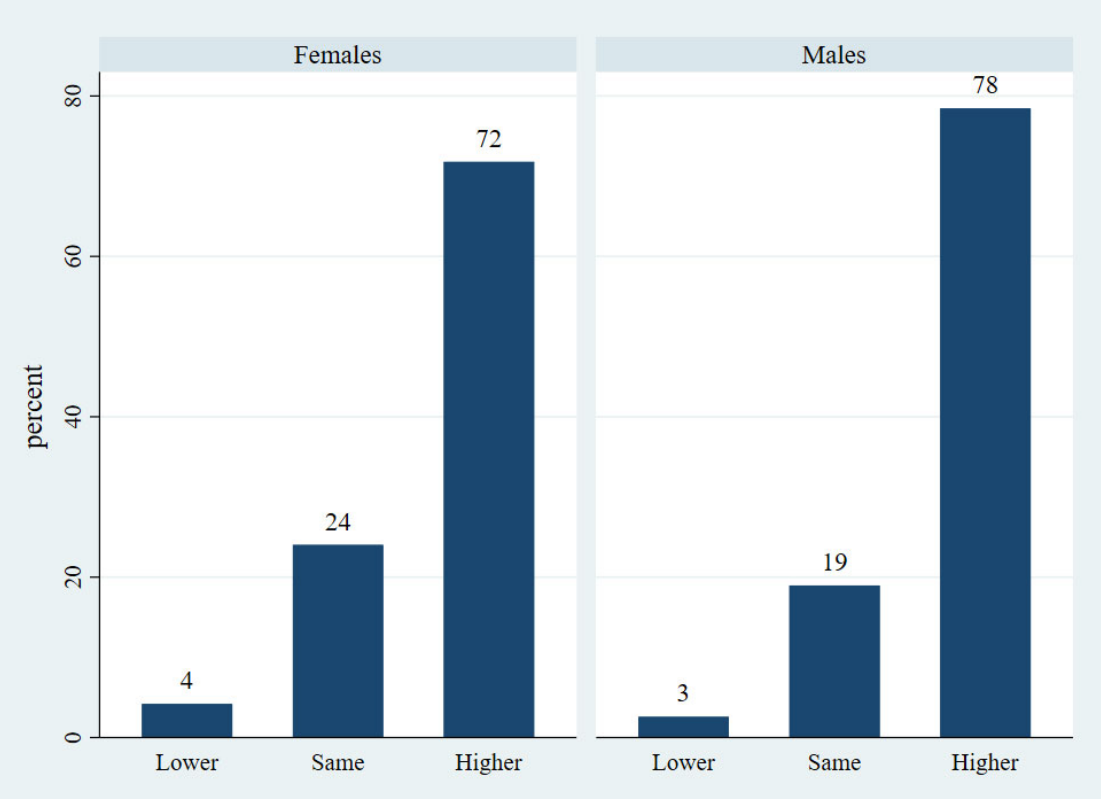

4.4 Analysis of how well migration predicts women's decision-making outcomes

Our analysis concludes by estimating the extent to which our two forms of migration - in-migration and out-migration - prediction women's involvement in decision-making. Given that migration during 2020 was significantly male-dominated, existing literature suggests potentially large impacts of this shock on women's involvement in agriculture and employment more broadly (Doss et al. 2021). Our main empirical specification, which we estimate using a logit model, is as follows:

$$
Y_{i a h j t}=\beta_{0}+\beta_{1} I_{i a h j t}+\beta_{2} O_{i a h j t}+\beta_{3} X_{h j t}+\delta_{a}+\alpha_{j}+\gamma_{t}+\varepsilon_{\text {iahjt }}
$$

Where $Y_{\text {iahjt }}$ is a dummy variable indicating a negative impact on decision-making for women within the household, $I$ is the number of in-migrants or returned members, and $O$ is the number of out-migrants or people who left the house in a specific period. $X_{h j t}$ are household controls including ethnicity of the household, housing characteristics (i.e. number of rooms in the house, shape of floors, main source of drinking water, electricity access and main fuel for cooking), if the respondent is head of household, if the respondent is currently working, and the number of members in the household that are currently working. Additionally, in our regressions we control for district fixed effects.

Given that our women's decision-making questions refer to changes during September - October 2019 and the same months in 2020, we focus on our migration variable that considers migration due to the pandemic (i.e., during 2020). Moreover, we analyzed three sets of respondents - all respondents (pooled), only female respondents, and only male respondents - in order to understand any gendered differences in the results. 
Table 4: Migration during the pandemic as a predictor of perceptions of women's involvement in decisions by res

\begin{tabular}{|c|c|c|c|c|c|c|c|c|c|}
\hline & (1) & $(2)$ & (3) & (4) & (5) & (6) & (7) & (8) & (9) \\
\hline \multirow[t]{2}{*}{ VARIABLES } & $\begin{array}{l}\text { Women } \\
\text { decision- } \\
\text { making } \\
\text { situation } \\
\text { was } \\
\text { negatively } \\
\text { affected } \\
\text { (income } \\
\text { spending) }\end{array}$ & $\begin{array}{l}\text { Women } \\
\text { decision- } \\
\text { making } \\
\text { situation } \\
\text { was } \\
\text { negatively } \\
\text { affected } \\
\text { (asset } \\
\text { manage.) }\end{array}$ & $\begin{array}{c}\text { Women } \\
\text { decision- } \\
\text { making } \\
\text { situation } \\
\text { was } \\
\text { negatively } \\
\text { affected (on } \\
\text { children) } \\
\end{array}$ & $\begin{array}{l}\text { Women } \\
\text { decision- } \\
\text { making } \\
\text { situation } \\
\text { was } \\
\text { negatively } \\
\text { affected } \\
\text { (income } \\
\text { spending) }\end{array}$ & $\begin{array}{c}\text { Women } \\
\text { decision- } \\
\text { making } \\
\text { situation was } \\
\text { negatively } \\
\text { affected (asset } \\
\text { manage.) }\end{array}$ & $\begin{array}{l}\text { Women } \\
\text { decision- } \\
\text { making } \\
\text { situation } \\
\text { was } \\
\text { negatively } \\
\text { affected (on } \\
\text { children) }\end{array}$ & $\begin{array}{l}\text { Women } \\
\text { decision- } \\
\text { making } \\
\text { situation } \\
\text { was } \\
\text { negatively } \\
\text { affected } \\
\text { (income } \\
\text { spending) }\end{array}$ & $\begin{array}{l}\text { Women } \\
\text { decision- } \\
\text { making } \\
\text { situation } \\
\text { was } \\
\text { negatively } \\
\text { affected } \\
\text { (asset } \\
\text { manage.) }\end{array}$ & $\begin{array}{c}\text { Women } \\
\text { decision- } \\
\text { making } \\
\text { situation } \\
\text { was } \\
\text { negatively } \\
\text { affected (on } \\
\text { children) } \\
\end{array}$ \\
\hline & \multicolumn{3}{|c|}{ All } & \multicolumn{3}{|c|}{ Women } & \multicolumn{3}{|c|}{ Men } \\
\hline $\mathrm{HH}$ w/ out-migrants 2020 & $\begin{array}{c}-0.073 * * * \\
(0.025)\end{array}$ & $\begin{array}{c}-0.052^{* *} \\
(0.024)\end{array}$ & $\begin{array}{l}-0.017 \\
(0.014)\end{array}$ & $\begin{array}{c}-0.066^{* *} \\
(0.029)\end{array}$ & $\begin{array}{l}-0.032 \\
(0.027)\end{array}$ & $\begin{array}{l}-0.012 \\
(0.016)\end{array}$ & $\begin{array}{c}-0.218^{* *} \\
(0.099)\end{array}$ & $\begin{array}{c}-0.311 * * * \\
(0.094)\end{array}$ & $\begin{array}{l}-0.090 \\
(0.134)\end{array}$ \\
\hline $\mathrm{HH}$ w/ in-migrants 2020 & $\begin{array}{c}0.019 \\
(0.057)\end{array}$ & $\begin{array}{l}-0.011 \\
(0.056)\end{array}$ & $\begin{array}{l}0.037 \\
(0.026)\end{array}$ & $\begin{array}{l}0.035 \\
(0.065)\end{array}$ & $\begin{array}{l}-0.044 \\
(0.069)\end{array}$ & $\begin{array}{c}0.012 \\
(0.043)\end{array}$ & $\begin{array}{l}-0.162 \\
(0.209)\end{array}$ & $\begin{array}{l}-0.161 \\
(0.180)\end{array}$ & \\
\hline HH Ethnicity: Uzbek & $\begin{array}{l}0.035 \\
(0.029)\end{array}$ & $\begin{array}{l}0.015 \\
(0.027)\end{array}$ & $\begin{array}{l}0.027^{*} \\
(0.015)\end{array}$ & $\begin{array}{l}0.043 \\
(0.032)\end{array}$ & $\begin{array}{l}0.037 \\
(0.029)\end{array}$ & $\begin{array}{l}0.025 \\
(0.018)\end{array}$ & $\begin{array}{l}-0.180 \\
(0.127)\end{array}$ & $\begin{array}{l}-0.221^{*} \\
(0.121)\end{array}$ & $\begin{array}{c}0.285 \\
(0.335)\end{array}$ \\
\hline HH Ethnicity: Turkmen & $\begin{array}{l}0.015 \\
(0.122)\end{array}$ & $\begin{array}{l}0.020 \\
(0.110)\end{array}$ & $\begin{array}{c}0.046 \\
(0.048)\end{array}$ & $\begin{array}{c}0.062 \\
(0.129)\end{array}$ & $\begin{array}{l}0.086 \\
(0.120)\end{array}$ & $\begin{array}{l}0.063 \\
(0.060)\end{array}$ & & & \\
\hline Number of rooms in the house & $\begin{array}{l}-0.006 \\
(0.008)\end{array}$ & $\begin{array}{l}-0.000 \\
(0.007)\end{array}$ & $\begin{array}{l}-0.005 \\
(0.005)\end{array}$ & $\begin{array}{l}-0.006 \\
(0.009)\end{array}$ & $\begin{array}{l}-0.002 \\
(0.008)\end{array}$ & $\begin{array}{l}-0.008 \\
(0.006)\end{array}$ & $\begin{array}{c}0.028 \\
(0.029)\end{array}$ & $\begin{array}{c}0.014 \\
(0.027)\end{array}$ & $\begin{array}{c}0.140^{* *} \\
(0.071)\end{array}$ \\
\hline $\begin{array}{l}\text { Floors: } 1=\text { Painted wood- } \\
\text { linoleum- concrete }\end{array}$ & $\begin{array}{l}0.008 \\
(0.030)\end{array}$ & $\begin{array}{c}0.002 \\
(0.029)\end{array}$ & $\begin{array}{l}-0.015 \\
(0.015)\end{array}$ & $\begin{array}{l}0.008 \\
(0.035)\end{array}$ & $\begin{array}{l}0.037 \\
(0.034)\end{array}$ & $\begin{array}{c}-0.012 \\
(0.018)\end{array}$ & $\begin{array}{c}0.012 \\
(0.092)\end{array}$ & $\begin{array}{l}-0.131^{*} \\
(0.079)\end{array}$ & $\begin{array}{c}0.038 \\
(0.126)\end{array}$ \\
\hline $\begin{array}{l}\text { Main source of drinking water: } \\
1=\text { piped into dwelling/yard or }\end{array}$ & 0.003 & -0.025 & 0.012 & -0.008 & -0.026 & 0.014 & 0.053 & 0.001 & 1.958 \\
\hline Has electricity & $\begin{array}{l}(0.028) \\
-0.076 \\
(0.217)\end{array}$ & $\begin{array}{l}(0.027) \\
-0.067 \\
(0.193)\end{array}$ & (0.015) & $(0.032)$ & $(0.030)$ & $(0.01 /)$ & $(0.116)$ & (0.114) & \\
\hline $\begin{array}{l}\text { Main fuel for cooking: } 1= \\
\text { Electricity or piped gas }\end{array}$ & $\begin{array}{l}0.030 \\
(0.029)\end{array}$ & $\begin{array}{l}-0.002 \\
(0.027)\end{array}$ & $\begin{array}{c}0.016 \\
(0.015)\end{array}$ & $\begin{array}{l}0.031 \\
(0.035)\end{array}$ & $\begin{array}{c}0.017 \\
(0.033)\end{array}$ & $\begin{array}{c}0.013 \\
(0.019)\end{array}$ & $\begin{array}{c}0.074 \\
(0.097)\end{array}$ & $\begin{array}{c}0.043 \\
(0.090)\end{array}$ & $\begin{array}{l}-0.294 \\
(0.209)\end{array}$ \\
\hline Head of household & $\begin{array}{l}-0.017 \\
(0.027)\end{array}$ & $\begin{array}{c}0.002 \\
(0.026)\end{array}$ & $\begin{array}{c}0.009 \\
(0.014)\end{array}$ & $\begin{array}{l}-0.037 \\
(0.034)\end{array}$ & $\begin{array}{l}-0.019 \\
(0.032)\end{array}$ & $\begin{array}{c}0.001 \\
(0.018)\end{array}$ & $\begin{array}{c}0.072 \\
(0.103)\end{array}$ & $\begin{array}{c}0.074 \\
(0.096)\end{array}$ & $\begin{array}{l}-0.426 \\
(0.282)\end{array}$ \\
\hline $\begin{array}{l}\text { Respondent is currently } \\
\text { working }\end{array}$ & $\begin{array}{c}-0.075^{* * *} \\
(0.025)\end{array}$ & $\begin{array}{c}-0.050^{* *} \\
(0.024)\end{array}$ & $\begin{array}{l}0.016 \\
(0.014)\end{array}$ & $\begin{array}{c}-0.071^{* *} \\
(0.029)\end{array}$ & $\begin{array}{c}-0.060^{* *} \\
(0.027)\end{array}$ & $\begin{array}{l}0.027 \\
(0.017)\end{array}$ & $\begin{array}{l}-0.084 \\
(0.087)\end{array}$ & $\begin{array}{l}-0.080 \\
(0.079)\end{array}$ & \\
\hline $\begin{array}{l}\text { Number of household members } \\
\text { with a job }\end{array}$ & $\begin{array}{l}-0.002 \\
(0.007)\end{array}$ & $\begin{array}{l}-0.000 \\
(0.007)\end{array}$ & $\begin{array}{l}-0.002 \\
(0.004)\end{array}$ & $\begin{array}{l}-0.005 \\
(0.008)\end{array}$ & $\begin{array}{l}-0.002 \\
(0.008)\end{array}$ & $\begin{array}{l}-0.000 \\
(0.004)\end{array}$ & $\begin{array}{c}0.031 \\
(0.024)\end{array}$ & $\begin{array}{c}0.042 * * \\
(0.021)\end{array}$ & $\begin{array}{c}0.059 \\
(0.051)\end{array}$ \\
\hline Observations & 1,029 & 1,034 & 963 & 794 & 796 & 731 & 106 & 107 & 26 \\
\hline
\end{tabular}

Standard errors in parentheses

$* * * \mathrm{p}<0.01, * * \mathrm{p}<0.05, * \mathrm{p}<0.1$

We include district fixed effects 
As we see in Table 4, out-migration, which we showed in Figure 9 and 10 to be a largely male-dominated phenomenon during this period, is associated with significant gains in women's decision-making power, as evidenced by declines in the likelihood that respondents report decision-making by women to have declined due to the pandemic. This is particularly true for decision-making about how to spend household income, where all respondent types report that out-migration is empowering for women in this decision-making domain. In contrast, we find no statistically significant impacts of in-migration on women's decisionmaking agency. 


\section{Discussion}

The covid-19 pandemic has had devastating effects globally; it has caused health crises and economic recessions, leading unemployment to spike and disrupting food systems and supply chains. In the heavily remittance-dependent context of Tajikistan, however, migration has continued - and appears to have become increasingly dominated by men. In this context, what has happened to women's outlooks on the economy and their household's economic performance? How has women's involvement in decision-making evolved? And to what extent do out-migration or in-migration predict changes in this decision-making power? We consider these questions using a September - October 2020 phone survey deployed in Khatlon province, Tajikistan that successfully tracked $87 \%$ of households that had been surveyed in person in 2018 (89\% of the time, we managed to talk to the same respondent). We find that both genders have similar expectations for their agricultural production (harvests), but women are slightly more likely to identify concerns with rising prices and a lack of access to financial services. Out-migration appears to have become increasingly male-dominated during the pandemic but continues to be an important household livelihood strategy.

Overall, we find little in the way of alarming evidence that women's involvement in intrahousehold decision-making declines as a result of the pandemic - though likely from a low base. However, we find that women are less likely to report improvements in their decision-making authority than are men. Further, we find that out-migration of household members, which is dominated by men, is associated with improvements in women's decision-making power, particularly with respect to decisions about how to spend household income. Overall, our results point to the need for additional analyses of the gendered impacts of shocks on women in the Central Asia region.

Our research provides both notes of optimism and pessimism. On the one hand, survey respondents' own economic outlooks are not overly negative, migration continues to operate as a safety valve, and reports of declining decision-making authority of women due to the pandemic are minimal. On the other hand, men have begun to dominate migration - possibly indicating a decline in opportunities for women - and women's reports about what has happened to their involvement in decision-making are less favorable than those of their male counterparts. Further, we see that male-outmigration is beneficial for women's involvement in decision-making, indicating that norms governing decision-making continue to disfavor women, with them only becoming empowered when men lead.

Our study is also not without limitations. We provide only correlations and cannot place a causal interpretation on any of our findings. Our outcomes are also ones asked only in the 2020 round of the survey (they were not present in 2018), which means we cannot directly study changes in responses about women's involvement in decision-making, but rather must rely on houseold reports on whether there have been improvements or declines (which is an admittedly coarse measure). Being a phone survey, we were also generally restricted in the amount of detail and information we could gather, and we were unable to gather information from multiple (opposite gender) respondents in each household, which would have permitted more thorough analysis of gender dynamics. 
New research is needed on what works to actually empower women in a setting such as that of Tajikistan - with patriarchal gender norms, but heavy dependence on migration. Also important is a greater understanding of within-household differences in reports about decision-making; our study unearths disparities, but more analysis is needed to see how and when each report deviates from the truth. Finally, a greater understanding is needed about how shocks influence migration dynamics - and to what extent they improve or worsens women's well-being on various dimensions. 


\section{References}

1. Akramov, K., and Shreedhar, G. (2012). "Economic development, external shocks, and food security in Tajikistan”, IFPRI Discussion Paper 1163. Washington, DC: International Food Policy Research Institute.

2. Ambler, K., Herskowitz, S., \& Maredia, M. K. (2021). "Are we done yet? Response fatigue and rural livelihoods." Journal of Development Economics, 153, 102736.

3. Doss,C., Qaisrani, A., Kosec,K., Slavchevska, V.,, Galiè, A., and Kawarazuka,N. (2021). "From the "feminization of agriculture" to gender equality". In Pyburn, Rhiannon, ed.; and van Eerdewijk, Anouka, ed. 2021. Advancing gender equality through agricultural and environmental research: Past, present, and future. Washington, DC: International Food Policy Research Institute (IFPRI).

4. FAO, WFP, UNECE, UNICEF, WHO, WMO. 2021. Regional Overview of Food Security and Nutrition in Europe and Central Asia 2020: Affordable healthy diets to address all forms of malnutrition for better health. Budapest. FAO, WFP, UN, UNICEF, WHO and WMO. https://doi.org/10.4060/cb3849en.

5. IFPRI/USAID. 2015. Feed the Future Tajikistan: Zone of Influence Interim Assessment Report. FebruaryMarch 2015. Washington, DC.

6. Kosec, K., Song, J., Zhao, H., and Holtemeyer, B. "The Gendered Impacts of Income Fluctuations on Household Departure, Labor Supply, and Human Capital Decisions: Evidence from Kyrgyzstan.” Forthcoming, Feminist Economics.

7. Murakami, E. 2021. "International migration and remittance effects on school enrollment of children staying behind: The evidence from Tajikistan." International Journal of Educational Development, 81, 102349

8. Statistical Agency under the President of the Republic of Tajikistan. 2015. Poverty Measurement in Tajikistan: A Methodological Note. Dushanbe. Tajikistan.

9. Statistical Agency under the President of the Republic of Tajikistan, Ministry of Health of Tajikistan, and ICF International. 2012. Tajikistan Demographic and Health Survey 2012. Dushanbe, Tajikistan and Calverton, MD, USA: SA, MOH, and ICF International.

10. Swinnen, J. and J. McDermott, Eds. 2020. COVID-19 and Global Food Security. Washington, DC.: International Food Policy Research Institute.

11. Takeshima, H., Akramov, K., Park, A., Ilyasov, J., Liu, Y., and Ergasheva, T., 2020. Agriculture-nutrition linkages with heterogeneous, unobserved returns and costs: Insights from Tajikistan. Agricultural Economics 51(4), 553-565.

12. Takeshima, H., Akramov, K., Ilyasov, J., and Ergasheva, T., 2021. Agriculture-nutrition linkages, cookingtime, intrahousehold equality among women and children: Evidence from Tajikistan. European Journal of Development Research (forthcoming).

13. Thomas, T., K. Akramov, R. Robertson, V. Nazareth, and J. Ilyasov. 2021. Climate Change, Agriculture and Crop Yields in Central Asia. Washington, DC. International Food Policy Research Institute. Discussion Paper (forthcoming)

14. UNDP. 2020. Impact of COVID-19 on Lives, Livelihoods and Micro, Small and Medium-Sized Enterprises (MSMEs) in Tajikistan. Dushanbe: UNDP. (https://www.tj.undp.org/content/tajikistan/en/home/library/impact-of-covid-19-on-lives--livelihoods-andmicro--small-and-me.html).

15. USAID. 2020. Feed the Future Tajikistan Agriculture and Water Activity. Final Report. Washington, DC.

16. World Bank. 2018. "World Development Indicators: Employment in agriculture (\% of total employment) (modeled ILO estimate) - Tajikistan"

17. World Bank. 2020. Tajikistan - Economic Slowdown Amid the Pandemic. (https://documents1.worldbank.org/curated/en/856841608613708986/pdf/Tajikistan-Economic-SlowdownAmid-the-Pandemic.pdf.

18. World Bank. 2021a. Tajikistan Country Gender Assessment. Washington, DC. (C) World Bank. https://openknowledge.worldbank.org/handle/10986/36657 License: CC BY 3.0 IGO.

19. World Bank. 2021b. Tajikistan Country Economic Update Summer 2021: Rebounding Economy, challenges Remain. Washington, DC. (C) World Bank. 
20. World Bank. 2021c. World Development Indicators. Washington, DC: The World Bank. Accessed on December 15, 2021.

21. World Bank, 2021d. Tajikistan Agrifood Sector and Publci Expenditure Review. Washington, DC: The World Bank. https://openknowledge.worldbank.org/bitstream/handle/10986/35972/Tajikistan-AgrifoodSector-and-Public-Expenditure-Review-Europe-and-Central-Asia-Region.pdf?sequence $=1$ \&isAllowed=y.

22. IFAD. 2020. Republic of Tajikistan Country Strategic Opportunities Programme 2019-2024

(https://webapps.ifad.org/members/eb/130/docs/EB-2020-130-R-19.pdf?attach=1)

23. Migrants and Refugees. 2020. "Migration profile: Tajikistan" 
APPENDIX A: VARIABLE'S DEFINITION

\begin{tabular}{|c|c|c|c|}
\hline Variable name & Definition & Type of variable & Source \\
\hline Age & $\begin{array}{l}\text { Age of the each household individual reported by the } \\
\text { main respondent. }\end{array}$ & Numeric & Survey 2018 \\
\hline Can read and write & $\begin{array}{l}\text { Individual can read and write in their own language. } \\
\text { Information reported by the main respondent. (1= can } \\
\text { read and write; } 0=\text { otherwise) }\end{array}$ & Dummy & Survey 2018 \\
\hline Currently attending school & $\begin{array}{l}\text { Individual is currently attending to school. Information } \\
\text { reported by the main respondent. ( } 1=\text { Attending to } \\
\text { school; } 0=\text { otherwise })\end{array}$ & Dummy & Survey 2018 \\
\hline Highest education level: Basic or less & $\begin{array}{l}\text { Highest education level of each household member. } \\
\text { Reported by the main respondent. ( } 1=\text { Basic education } \\
\text { [grades } 1 \text { to } 9 \text { ] or less; } 0=\text { otherwise) }\end{array}$ & Dummy & Survey 2018 \\
\hline Highest education level: Secondary & $\begin{array}{l}\text { Highest education level of each household member. } \\
\text { Reported by the main respondent. ( } 1=\text { Secondary; } 0= \\
\text { otherwise) }\end{array}$ & Dummy & Survey 2018 \\
\hline Highest education level: Tertiary or higher & $\begin{array}{l}\text { Highest education level of each household member. } \\
\text { Reported by the main respondent. ( } 1=\text { Tertiary or higher; } \\
0=\text { otherwise) }\end{array}$ & Dummy & Survey 2018 \\
\hline Russian proficient & $\begin{array}{l}\text { Individual has a level of Russian proficiency of } \\
\text { satisfactory, good or excellent }=1 ; 0=\text { otherwise. }\end{array}$ & Dummy & Survey 2018 \\
\hline Sex & $\begin{array}{l}\text { Sex of the household member: Male }=1 ; 0=\text { otherwise. } \\
\text { Reported by the main respondent. }\end{array}$ & Dummy & Survey 2018 \\
\hline $\begin{array}{l}\text { Women decision- making situation was } \\
\text { negatively affected - Income Spending) }\end{array}$ & $\begin{array}{l}\text { Indicates if women's decision-making situation was } \\
\text { negatively affected within the housheold in matters of } \\
\text { income spending. Reported by the main respondent. }\end{array}$ & Dummy & Survey 2020 \\
\hline
\end{tabular}




\begin{tabular}{|c|c|c|c|}
\hline Variable name & Definition & Type of variable & Source \\
\hline $\begin{array}{l}\text { Women decision- making situation was } \\
\text { negatively affected - Asset management }\end{array}$ & $\begin{array}{l}\text { Indicates if women's decision-making situation was } \\
\text { negatively affected within the household in matters of } \\
\text { asset management. Reported by the main respondent. }\end{array}$ & Dummy & Survey 2020 \\
\hline $\begin{array}{l}\text { Women decision- making situation was } \\
\text { negatively affected - About children }\end{array}$ & $\begin{array}{l}\text { Indicates if women's decision-making situation was } \\
\text { negatively affected within the housheold in matters } \\
\text { regarding children. Reported by the main respondent. }\end{array}$ & Dummy & Survey 2020 \\
\hline Household with out-migrants 2020 & $\begin{array}{l}\text { Indicates if the household reported any out migrants that } \\
\text { went away in } 2020(=1) \text { or not }(=0) \text {. Reported by the } \\
\text { main respondent. }\end{array}$ & Dummy & Survey 2020 \\
\hline Household with in-migrants 2020 & $\begin{array}{l}\text { Indicates if the household reported any in migrants that } \\
\text { returned in } 2020(=1) \text { or not }(=0) \text {. Reported by the main } \\
\text { respondent. }\end{array}$ & Dummy & Survey 2020 \\
\hline Household ethnicity: Tajik & $\begin{array}{l}\text { Indicates ethnicity of the household: } 1 \text { if Tajik; } 0 \text { if } \\
\text { otherwise. Reported by the main respondent. }\end{array}$ & Dummy & Survey 2018 \\
\hline Household ethnicity: Uzbek & $\begin{array}{l}\text { Indicates ethnicity of the household: } 1 \text { if Uzbek; } 0 \text { if } \\
\text { otherwise. Reported by the main respondent. }\end{array}$ & Dummy & Survey 2018 \\
\hline Household ethnicity: Turkmen & $\begin{array}{l}\text { Indicates ethnicity of the household: } 1 \text { if Turkmen; } 0 \text { if } \\
\text { otherwise. Reported by the main respondent. }\end{array}$ & Dummy & Survey 2018 \\
\hline Number of rooms in the house & $\begin{array}{l}\text { Number of rooms that the housing of the household has. } \\
\text { Reported by the main respondent. }\end{array}$ & Numeric & Survey 2018 \\
\hline
\end{tabular}




\begin{tabular}{|c|c|c|c|}
\hline Variable name & Definition & Type of variable & Source \\
\hline Floors type & $\begin{array}{l}\text { Indicates if the household has: painted/wood floors, } \\
\text { linoleum or concrete }=1 ; 0 \text { if otherwise. Reported by the } \\
\text { main respondent. }\end{array}$ & Dummy & Survey 2018 \\
\hline Main source of drinking water & $\begin{array}{l}\text { Indicates what is the main source of drinking water: } 1= \\
\text { piped into dwelling/yard or tap; } 0 \text { if otherwise. Reported } \\
\text { by the main respondent. }\end{array}$ & Dummy & Survey 2018 \\
\hline Has electricity & $\begin{array}{l}\text { Indicates if the household has access to electricity in its } \\
\text { housing facility }(=1) \text { or not }(=0) \text {. Reported by the main } \\
\text { respondent. }\end{array}$ & Dummy & Survey 2018 \\
\hline Main fuel for cooking & $\begin{array}{l}\text { Indicates the main fuel of cooking used by the household: } \\
1=\text { Electricity or piped gas; } 0=\text { otherwise }\end{array}$ & Dummy & Survey 2018 \\
\hline Head of household & $\begin{array}{l}\text { Indicates if the main respondent is the head of the } \\
\text { household }(=1) \text { or not }(=0) \text {. Reported by the main } \\
\text { respondent. }\end{array}$ & Dummy & Survey 2020 \\
\hline Respondent is currently working & $\begin{array}{l}\text { Indicates if the main respondent is currently working }(=1) \\
\text { or not }(=0) . \text { Reported by the main respondent. }\end{array}$ & Dummy & Survey 2020 \\
\hline Number of household members with a job & $\begin{array}{l}\text { Indicates the number of household members that have a } \\
\text { job. Reported by the new respondent. }\end{array}$ & Numeric & Survey 2020 \\
\hline
\end{tabular}




\section{APPENDIX B: ADDITIONAL FIGURES}

\section{Changes in household income}

Figure B1: Has there been any change in total household income due to the COVID-19 pandemic?

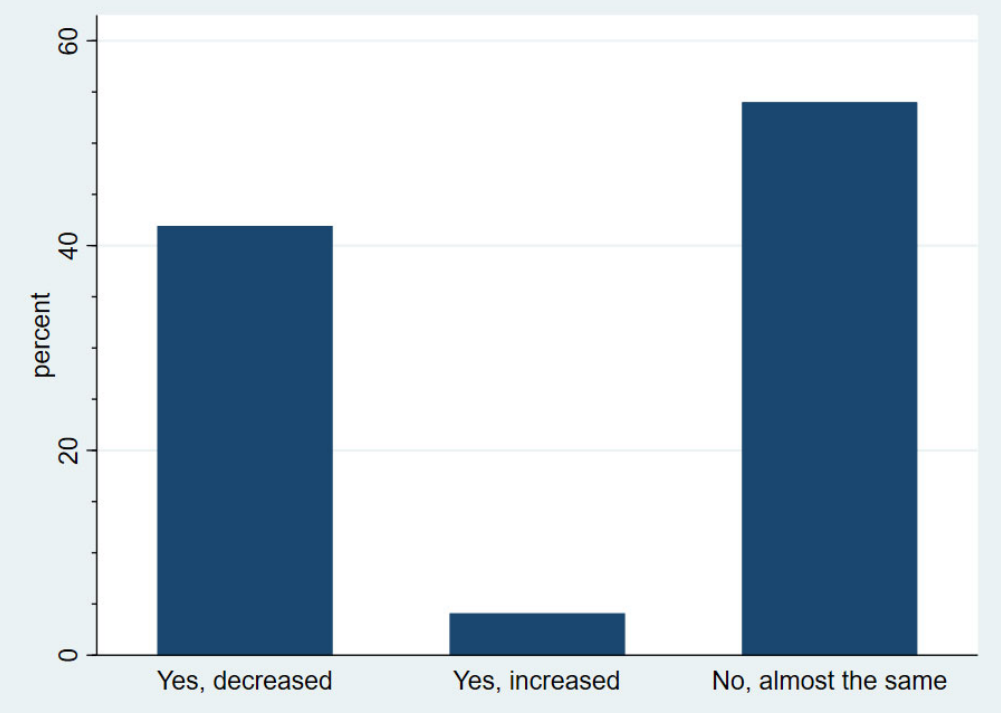

Figure B2: If income changed, by what percentage? Results by quartile of 2018 asset wealth

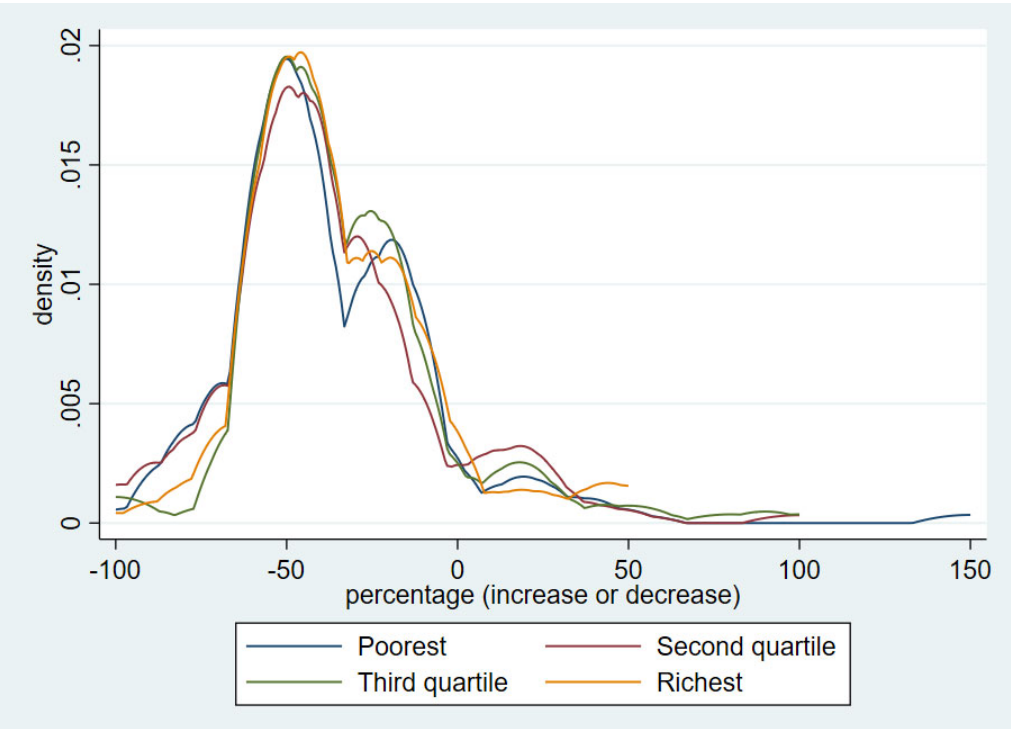




\section{Migration}

\subsection{Migration during 2020}

Figure B3: Share of households that reported migrants (either type)

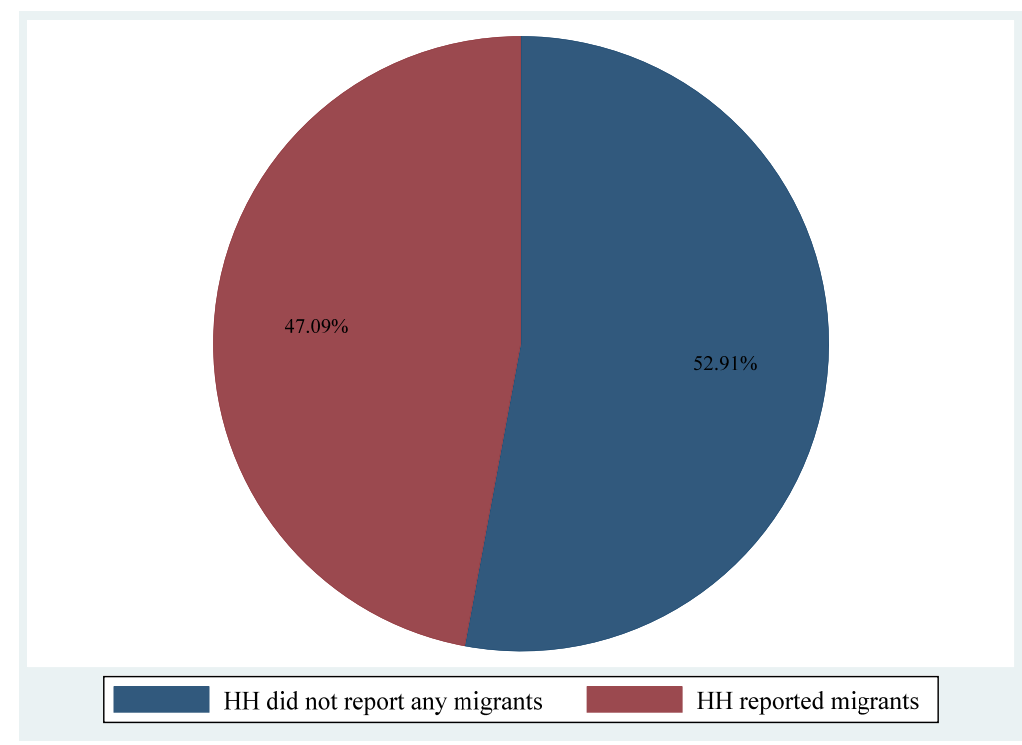

2.2. Migration during the period between 2018 and 2020

Figure B4: Share of households that reported migrants (either type)

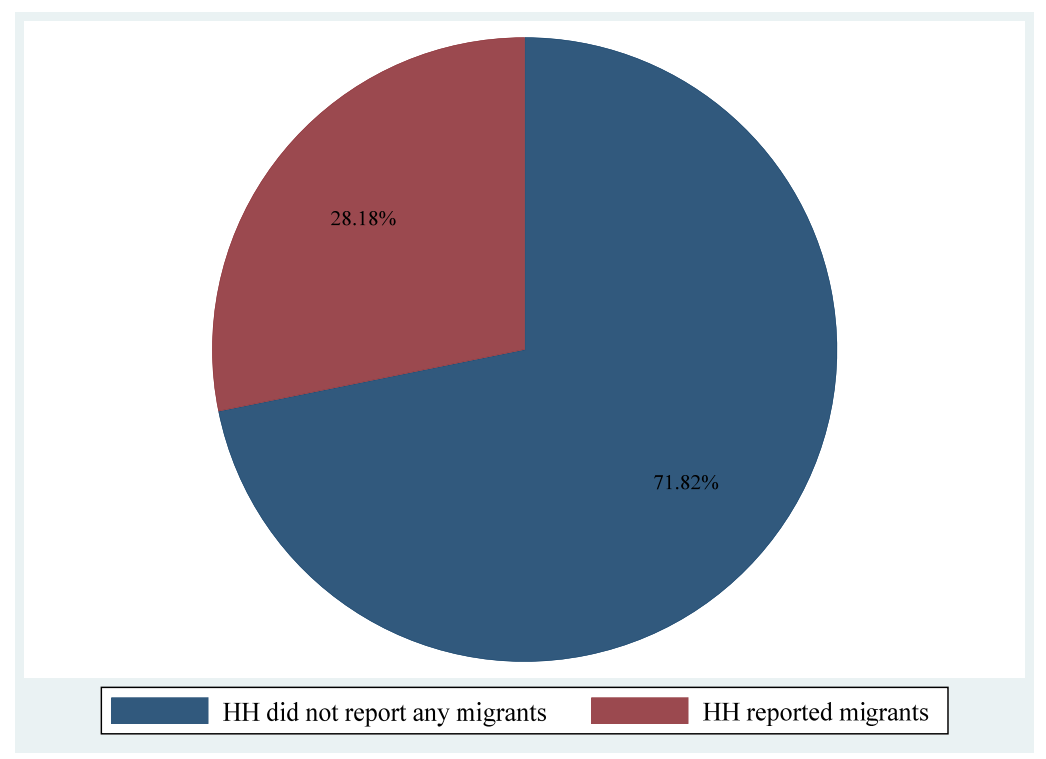

